\title{
Sorption of Arsenic to Biogenic Iron (Oxyhydr)oxides Produced in Circumneutral Environments
}

\author{
Tyler D. Sowers ${ }^{1, \S}$, James M. Harrington ${ }^{2}$, Matthew L. Polizzotto ${ }^{1}$, and \\ Owen W. Duckworth ${ }^{1, *}$
}


1 Abstract. Arsenic (As) is a widespread and problematic pollutant that can be derived

2 from natural or anthropogenic sources. Iron (oxyhydr)oxides readily sorb As and thus

3 play critical roles in As cycling in terrestrial environments; however, little is known about

4 the affinity and mechanism of As sorption by biogenic iron (oxyhydr)oxides formed in

5 circumneutral environments. To investigate this, we conducted sorption isotherm and

6 kinetics experiments to compare $\mathrm{As}(\mathrm{V})$ and $\mathrm{As}(\mathrm{III})$ sorption to synthetic 2-line

7 ferrihydrite and iron biominerals harvested from the hyporheic zone of an

8 uncontaminated creek. Inductively coupled plasma mass spectrometry (ICP-MS) was

9 used to quantify both $\mathrm{As}(\mathrm{V})$ and $\mathrm{As}(\mathrm{III})$, and X-ray absorption spectroscopy (XAS) was

10 utilized to obtain $\mathrm{As}$ and $\mathrm{Fe} \mathrm{K}$-edge spectra for $\mathrm{As}(\mathrm{V})$ and $\mathrm{As}(\mathrm{III})$ sorbed to

11 environmentally collected and laboratory produced Fe(III) minerals. All environmental

$12 \mathrm{Fe}(\mathrm{III})$ biominerals were determined to be structurally similar to 2-line ferrihydrite.

13 However, environmental $\mathrm{Fe}$ (III) biominerals have a surface area normalized affinity for

$14 \mathrm{As}(\mathrm{V})$ and for $\mathrm{As}(\mathrm{III})$ that is greater than or equivalent to synthetic 2-line ferrihydrite.

15 Whereas the extent of sorption was similar for As(III) on all minerals, As(V) sorption to

16 environmental $\mathrm{Fe}(\mathrm{III})$ biominerals was approximately three times higher than what was

17 observed for synthetic 2-line ferrihydrite. Structural modeling of EXAFS spectra revealed

18 that the same surface complexation structure was formed by $\mathrm{As}(\mathrm{V})$ and by $\mathrm{As}(\mathrm{III})$ on

19 environmental $\mathrm{Fe}(\mathrm{III})$ biominerals and ferrihydrite. These results suggest that, despite

20 similarities in binding mechanisms, Fe(III) biominerals may be more reactive sorbents

21 that synthetic surrogates often used to model environmental reactivity. 


\section{INTRODUCTION}

24 Arsenic (As) is a widespread and problematic pollutant that impacts the health of 25 approximately 150 million people (Brammer and Ravenscroft, 2009). Many adverse

26 health effects, including increased cancer rates, birth defects, neurological issues, and

27 diabetes, are associated with chronic As exposure (Kleinert et al., 2011; Meharg and 28 Zhao, 2012). Human exposure to As may arise from both anthropogenic and natural

29 sources (Smedley and Kinniburgh, 2013; Muehe and Kappler, 2014), which are 30 geographically widespread. For example, runoff of As-containing pesticides and mine

31 drainage (Welch et al., 2000; Mandal and Suzuki, 2002) are major anthropogenic sources

32 of As, especially in the Americas, resulting in contamination of groundwater in regions of

33 southwestern United States and Mexico (Smedley and Kinniburgh, 2013). Natural

34 sources of As contamination (i.e., weathering of As-bearing minerals in rocks and

35 reductive dissolution of iron-bearing soil and sediments) present an even greater hazard

36 to human health, and, in Southern Asia as well as South America, have developed into

37 major societal concerns (Goldberg, 2002; Smedley and Kinniburgh, 2002). As a result,

38 research seeking to elucidate the sources and mechanisms of As solubilization and

39 mobilization has intensified over the last 15 years (Meharg and Zhao, 2012).

$40 \quad$ Field and laboratory studies have identified iron (oxyhydr)oxides as key sorbents

41 that sequester As (Wilkie and Hering, 1996; Raven et al., 1998; Goldberg and Johnston,

42 2001; Mandal and Suzuki, 2002; Dixit and Hering, 2003; Cornell and Schwertmann,

43 2004; Mohan and Pittman Jr, 2007). Consequently, it is important to understand the

44 factors controlling As interactions with these mineral surfaces. Major conditions

45 controlling As retention on mineral surfaces include redox conditions, $\mathrm{pH}$, and 
46 concentrations of competitive ions. The effects of these conditions on surface chemical

47 processes are well understood for many minerals (Pierce and Moore, 1982; Bowell, 1994;

48 Fendorf et al., 1997; Giménez et al., 2007; Redman et al., 2002; Bauer and Blodau,

49 2006), including both crystalline and poorly ordered synthetic iron minerals (e.g.,

50 ferrihydrite (Waychunas et al., 1993; Raven et al., 1998; Jambor and Dutrizac, 1998; Jain

51 and Loeppert, 2000; Grafe et al., 2002; Dixit and Hering, 2003; Michel et al., 2007a;

52 Borch et al., 2009; Cismasu et al., 2011; Cismasu et al., 2012)).

53 Although abiotically synthesized ferrihydrite is often used as an experimental

54 surrogate for poorly ordered $\mathrm{Fe}(\mathrm{III})$ (oxyhydr)oxide minerals that are environmentally

55 ubiquitous (Jambor and Dutrizac, 1998), there is a growing recognition that bacteriogenic

56 Fe minerals are common in natural waters and sediments, forming specifically at redox

57 gradients (e.g., circumneutral $\mathrm{Fe}(\mathrm{II})$-rich groundwater discharges into quiescent aerobic

58 surface water) (Emerson and Weiss, 2004; Ferris, 2005; Duckworth et al., 2009; Emerson

59 et al., 2010; Posth et al., 2010; Gault et al., 2011; Roden et al., 2012, Posth et al., 2014).

60 These biominerals may have important structural differences (decreased crystallinity,

61 reduced crystal domain size, and increased surface area (Ferris et al., 2000; Ferris, 2005;

62 Hohmann et al., 2009; Posth et al., 2010; Cismasu et al., 2011)), as well as incorporated

63 bacterial biomass and other cell-derived organic matter (Hohmann et al., 2009; Schadler

64 et al., 2009; Muehe et al., 2013; Schmid et al., 2014; Hao et al., 2016), which may result

65 in a sorption reactivity that differs significantly from synthetic ferrihydrite. Despite the

66 potential importance of biogenic Fe(III) (oxyhydr)oxides to As cycling, few studies

67 (Keim, 2011; Kleinert et al., 2011; Muehe et al., 2013; Xiu et al, 2015) have examined 
68 sorption of As by biogenic Fe(III) (oxyhydr)oxides formed in circumneutral

69 environments, resulting in a significant gap in our knowledge (Emerson et al., 2010).

70 A better understanding of As sorption onto biogenic Fe(III) biominerals that form

71 at redox gradients in natural waters is needed to develop improved models of As transport

72 and sequestration in the environment. Accordingly, the objectives of this study were to 1)

73 determine the extent of As sorption to iron biominerals originally formed in aquatic

74 environments, and 2) identify surface complexes formed by As sorbed to environmental

75 iron biominerals.

\section{MATERIALS AND METHODS}

\section{2.1. Materials}

All solutions were prepared in Type I deionized water. All chemicals used were

80 reagent grade and provided by Fisher Scientific, unless otherwise specified.

\subsection{Environmental Fe(III) Biomineral Sampling and Sorbent Preparation}

83 All environmental Fe(III) biominerals used in experiments were collected from 84 Rocky Branch Creek near the Pullen Road Overpass (35 46' 48" N, $8^{\circ} 40^{\prime} 2^{\prime \prime}$ W; Raleigh,

85 North Carolina; EA Fig. S1). This site has a perennial occurrence of Fe(III) mineral-

86 bearing biofilms at multiple locations along the stream $(\mathrm{pH}=6.3-6.8)$. Submerged

87 "fluffy" orange biofilm/mineral assemblages were sampled from the south bank of the

88 stream via syringe and repeatedly transferred into $500 \mathrm{~mL}$ polypropylene bottles. All

89 sampling was completed at the same location to reduce the effect of variable

90 environmental conditions on $\mathrm{Fe}(\mathrm{III})$ biomineral structure and components. From here on 
91 out, a naming convention that utilizes the date of sampling (five sampling dates in 2015-

92 2016) is used to identify specific environmental Fe(III) biomineral samples.

93 In the laboratory, the mineral suspensions were transferred into $50 \mathrm{~mL}$

94 polypropylene centrifuge tubes and centrifuged for 10 minutes at ca. 10,000 g (RCF). The

95 supernatant was decanted, and then the remaining sample was vortexed and mixed with

96 other samples. This process was repeated to produce a pooled Fe(III) biomineral stock,

97 which was stored in a freezer at approximately $-20^{\circ} \mathrm{C}$ until further use. Before freezing, a

$98100 \mathrm{mg}$ subsample (wet mass basis) was taken and allowed to dry at $80^{\circ} \mathrm{C}$ in an oven for

99 approximately 24 hours to calculate a dry mass percent, which was used to apply a

100 consistent solids loading from suspensions for all subsequent experiments.

101

\section{2.3. Synthetic 2-line Ferrihydrite Synthesis}

103 Two-line ferrihydrite was abiotically synthesized according to established

104 procedures (Cornell and Schwertmann, 2003). Briefly, $40 \mathrm{~g}$ of $\mathrm{Fe}\left(\mathrm{NO}_{3}\right)_{3} \cdot 9 \mathrm{H}_{2} \mathrm{O}$ was

105 dissolved in $500 \mathrm{~mL}$ of deionized (DI) water. In order to raise $\mathrm{pH}, 330 \mathrm{~mL}$ of $1 \mathrm{M} \mathrm{KOH}$

106 was added to the $\mathrm{Fe}\left(\mathrm{NO}_{3}\right)_{3}$ with vigorous stirring. The $\mathrm{pH}$ of the solution was monitored

107 constantly during the addition of the final $20 \mathrm{~mL}$ of $1 \mathrm{M} \mathrm{KOH}$. Upon reaching $\mathrm{pH}=7.5 \pm$

1080.5 , the solution was centrifuged and washed with DI water. The procedure resulted in

109 the formation of ca. $10 \mathrm{~g}$ of 2-line ferrihydrite. All synthesized minerals were stored in a

110 freezer at approximately $-20^{\circ} \mathrm{C}$ until further use.

111

\section{2.4. Characterization of Fe(III) Minerals}


113 All Fe(III) minerals were characterized to assess composition. The $\mathrm{C}$ content was

114 determined by total combustion using a Perkin Elmer 2400 CHNS analyzer. The Fe

115 content was estimated for environmental Fe(III) biomineral samples by performing a

116 citrate-bicarbonate-dithionite (CBD) extraction (Klute, 1965). For this extraction, $100 \mathrm{mg}$

117 subsamples (dry mass basis) were weighed followed by the addition of $20 \mathrm{~mL}$ of sodium

118 citrate dihydrate $(0.3 \mathrm{M})$ and $2.5 \mathrm{~mL}$ of sodium bicarbonate $(1 \mathrm{M})$. Sample suspensions

119 were shaken and heated to ca. $80^{\circ} \mathrm{C}$ in a water bath. After $1 \mathrm{~g}$ of sodium dithionite was

120 added, samples were held at $80^{\circ} \mathrm{C}$ for 30 minutes with intermittent shaking. Samples

121 were then centrifuged, filtered, and analyzed for aqueous Fe using a Thermo-Fisher iCE

1223000 flame atomic adsorption spectrometer.

123 The morphology, phase, and surface properties of $\mathrm{Fe}(\mathrm{III})$ minerals were also

124 characterized. Brunauer-Emmett-Teller (BET) analysis was conducted using a

125 Quantachrome: Monosorb surface area analyzer to determine surface area. To determine

126 particle phase, X-ray diffraction (XRD) was conducted by using a Rigaku (The

127 Woodlands, TX, USA) SmartLab X-Ray Diffractometer, and Fe K-edge X-ray absorption

128 spectroscopy (XAS) was conducted as described below. Transmission electron

129 microscopy (TEM) was performed to elucidate morphology. Fe(III) mineral suspensions

130 were pipetted onto a silicon nitride chip, allowed to air dry, and analyzed using a

131 scanning transmission electron microscope (JEOL 2000FX) operated at 1 atm. In

132 addition, $\zeta$-potential analyses were conducted in triplicate to determine the surface charge

133 of sorbents at $\mathrm{pH}=7$ by using a Malvern Zetasizer Nano $\mathrm{Z}$ (Worcestershire, UK).

\section{2.5. Rates of Arsenic Sorption to Fe(III) Minerals}


136 To assess the rate of arsenate and arsenite sorption to iron minerals, stock

137 solutions $\left(500 \mathrm{mg} \mathrm{L}^{-1}\right)$ were prepared from reagent grade $\mathrm{Na}_{2} \mathrm{HAs}(\mathrm{V}) \mathrm{O}_{4} \cdot 7 \mathrm{H}_{2} \mathrm{O}$ and

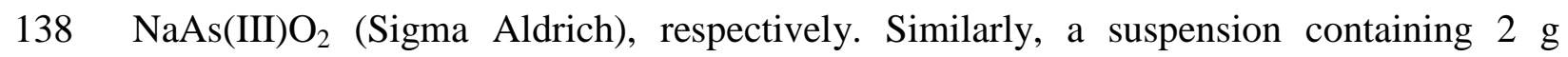

139 sorbent (dry mass basis) $\mathrm{L}^{-1}$ in $0.01 \mathrm{M} \mathrm{NaCl}$ was prepared such that final suspension

140 volume was $250 \mathrm{~mL}$ (1:125 solid:solution mass ratio). The $\mathrm{pH}$ of each solution was

141 adjusted to $\mathrm{pH}=7$ via $\mathrm{HCl}$ and $\mathrm{NaOH}$ additions and monitored using a XL20

$142 \mathrm{pH} /$ conductivity meter. This $\mathrm{pH}$ was chosen to approximate the circumneutral conditions

143 seen in surface waters from where environmental Fe(III) biomineral mass was collected.

144 A magnetic stir bar was used in the reactor to agitate the suspension and aluminum foil

145 was used as a cover to exclude stray light.

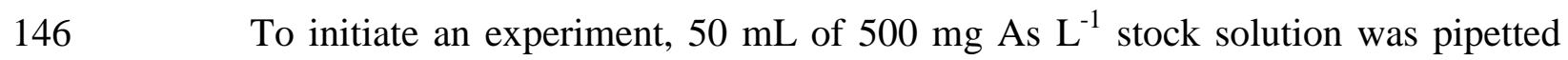

147 with continuous stirring into the sorbent reactor containing either synthetic 2-line

148 ferrihydrite or an environmental Fe(III) biomineral sample such that the initial As

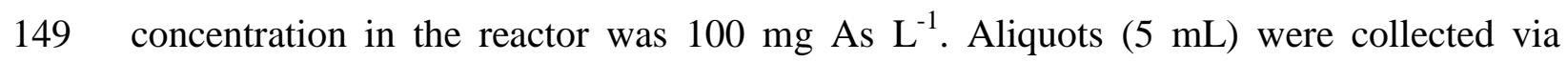

150 syringe and filtered through $0.45 \mu \mathrm{m}$ filters periodically over 3 days, with more samples

151 collected near the start of the experiment. These samples were then stored in a

152 refrigerator at $4^{\circ} \mathrm{C}$ until further analysis. The experiments were performed in duplicate.

153 Inductively coupled plasma-mass spectrometry (ICP-MS) analysis was conducted

154 by using a Thermo $\mathrm{X}$ Series II for all aqueous As samples from kinetics and isotherm

155 experiments in order to quantify total dissolved As. Prior to conducting ICP-MS analysis,

156 all samples were diluted using $0.01 \mathrm{M} \mathrm{NaCl}$ containing $1 \%$ nitric acid and spiked with an

157 internal calibration standard of $1 \mathrm{mg} \mathrm{L}^{-1}$ yttrium and indium (final concentration of $10 \mu \mathrm{g}$

$\left.158 \mathrm{~L}^{-1}\right)$. Samples were analyzed in collision cell mode with a $10 \% \mathrm{H}_{2} / \mathrm{He}$ gas mix to exclude 
159 the $\mathrm{ArCl}$ polyatomic interference. System performance was optimized on a daily basis by

160 analysis of a $10 \mathrm{ppb}$ solution of $\mathrm{In} / \mathrm{Ce}$ and system suitability was determined by periodic

161 reanalysis of a mid-range calibration standard.

162

\section{2.6. Adsorption Isotherms}

164 The extent of $\mathrm{As}(\mathrm{V})$ and $\mathrm{As}(\mathrm{III})$ sorption to synthetic 2-line ferrihydrite and 165 environmental Fe(III) biominerals was quantified using approaches based on previously 166 published methods (Dixit and Hering, 2003; Raven et al., 1998). For all isotherms, initial 167 As concentrations ranging up to $200 \mathrm{mg} \mathrm{L}^{-1}$ were tested. Sorbent suspensions of $2 \mathrm{~g} \mathrm{~L}^{-1}$ 168 were made for both synthetic 2-line ferrihydrite and environmental Fe(III) biominerals in

$16950 \mathrm{~mL}$ polypropylene centrifuge tubes. Arsenic stock solutions $\left(500 \mathrm{mg} \mathrm{L}^{-1}\right)$ and sorbent 170 suspensions were adjusted to $\mathrm{pH} 7.0 \pm 0.1$ by using $\mathrm{HCl}$ and $\mathrm{NaOH}$, with both in an 171 electrolyte matrix $0.1 \mathrm{M} \mathrm{NaOH}$. Varying volumes of As stock were pipetted into sorbent 172 suspension samples to establish a range of initial As concentrations. The resulting sample 173 was then mixed by using a vortex genie, and $\mathrm{pH}$ was monitored (and readjusted as 174 necessary to $\mathrm{pH} 7 \pm 0.1$ ) for all samples using a XL20 pH/conductivity meter. Samples 175 were then loaded onto a MX RD Pro rotary mixer for 48 hours. Samples were checked 176 for $\mathrm{pH}$ changes and were adjusted to $\mathrm{pH} 7.0 \pm 0.1$. After 48 hours, samples were 177 centrifuged at ca. 10,000 g RCF for 10 minutes, pipetted into $20 \mathrm{~mL}$ syringes, and filtered 178 at $0.45 \mu \mathrm{m}$ (nylon membrane). Collected filtrate was then stored at approximately $4^{\circ} \mathrm{C}$ in 179 a refrigerator for later analysis. These experiments were performed in triplicate for 180 synthetic 2-line ferrihydrite and in duplicate for environmental Fe(III) biomineral. 
The isotherm procedure was performed for both $\mathrm{As}(\mathrm{V})$ and $\mathrm{As}(\mathrm{III})$; however, to

182 limit unwanted oxidation of As(III) to As(V) (Kim \& Nriagu, 2000), As(III) experiments

183 were performed in a glovebag with an approximately $2 \% \mathrm{O}_{2}$ atmosphere set by using a

$184 \mathrm{~N}_{2}$ gas mixture $\left(99 \% \mathrm{~N}_{2}, 1 \% \mathrm{O}_{2}\right)$ and monitored intermittently using a NeoSport oxygen

185 probe. Originally, an anoxic glovebox was used for As(III) experiments but iron in the

186 sorbent was found to have reduced over the course of the 48 hour reaction time,

187 suggesting the presence of Fe(III)-reducing bacteria in the environmental sample, as has

188 previously been noted at other locations (Roden et al., 2012).

189 Arsenic in solution was measured by ICP-MS. By measuring the difference

190 between the As concentrations before and after sorption (i.e., As lost from solution), the

191 sorbed As was calculated. For series of As data at different concentrations, a 192 preprogramed Excel spreadsheet was used to fit isotherm data to both Langmuir and

193 Freundlich fits (Bolster and Hornberger, 2007) using non-linear optimization. For

194 selected aqueous samples, speciation analysis was also conducted using ultra-high

195 performance liquid chromatography-sector field-inductively coupled plasma mass

196 spectrometry [UHPLC-SF-ICP-MS, UHPLC system: Waters ACQUITY (Milford, MA,

197 USA); SF-ICP-MS: Thermo Element 2] to determine the concentrations of As(V) and

198 As(III). Separation was performed by UHPLC-SF-ICP-MS using a previously described

199 method (Milstein et al., 2003; Kim et al., 2013). Arsenic species were quantified with a

200 standard curve constructed using solutions made from $\mathrm{Na}_{2} \mathrm{HAs}(\mathrm{V}) \mathrm{O}_{4} \cdot 7 \mathrm{H}_{2} \mathrm{O}$ or

$201 \mathrm{NaAs}(\mathrm{III}) \mathrm{O}_{2}$. Samples were analyzed using a Hamilton PRP-X100 liquid chromatography

202 column $(4.6$ x $150 \mathrm{~mm} ; 5 \mu \mathrm{m}$ particle size $)$. The UHPLC flow rate and mobile phase 203 gradient are summarized in EA Table S1. 


\subsection{X-ray Absorption Spectroscopy}

Arsenic and Fe K-edge XAS spectra were collected at the Stanford Synchrotron

207 Radiation Lightsource (SSRL) on beamlines 4-1, 4-3, and 11-2. Environmental samples

208 were collected on 6/19/15 and 2/1/16, and are interpreted as being representative of all

209 environment samples. Arsenic K-edge spectra obtained for As-loaded Fe(III) mineral

210 samples were performed at low and high As concentrations (Fe:As ratios of 300:1 and

$21162.5: 1$, respectively). Spectra were energy calibrated by adjusting the $E_{0}$ to a metal foil

212 (Fe K-edge and Au L-edge used for Fe and As calibration, respectively). For Fe K-edge

213 spectra, synthetic samples were collected in transmission mode whereas environmental

214 samples were collected in florescence mode using a Lytle detector. Arsenic K-edge

215 spectra were collected at room temperature $[\mathrm{As}(\mathrm{V})]$ or in an liquid nitrogen cryostat [to

216 prevent photooxidation of As(III)] on beamline 11-2 in fluorescence with a 100-element

217 Ge detector. On 4-1 and 11-2, the incident beam was detuned by $35 \%$ and energy

218 selected by using a variable-exit $\mathrm{Si}(220)$ double-crystal monochromator to reduce

219 harmonics. On 4-3, rhodium-coated mirrors were used to reject harmonics and energy

220 was selected with a $\mathrm{Si}(111)$ monochrometer. For fluorescence measurements, spectra

221 were collected using Soller slits and a Z-1 X-ray filter (Ge or Mn) to improve the signal-

222 to-noise ratio. Multiple spectra were collected for each sample, with no evidence of beam

223 damage in successive scans, and averaged to improve the signal-to-noise ratio.

224 Both Fe and As K-edge spectra were energy calibrated, averaged, background-

225 subtracted, splined, and fit in R-space (Kelly et al., 2008) using the SIXPACK interface

226 (Webb, 2005b), which makes use of the IFEFFIT code (Newville, 2001). Normalized Fe 
227 XANES and Fe EXAFS linear combination fitting was conducted in SIXPACK for

228 environmental $\mathrm{Fe}(\mathrm{III})$ biominerals using $\mathrm{Fe}(\mathrm{III})$ standards in order to probe $\mathrm{Fe}(\mathrm{III})$

229 mineral phase and structure (Kelly et al., 2008). Components found to make up less than

$23010 \%$ of the spectral reconstruction were removed, and fits were recalculated using

231 remaining standards. A list of all standards (O'day et al., 2004; Harrington et al., 2012)

232 considered in fits is shown in the electronic annex (EA Table S2), with those used in final

233 fits shown in bold.

234 Structural (shell by shell) fitting analysis was also performed for As EXAFS

235 spectra utilizing SIXPACK software. Spectra for As-bearing environmental Fe(III)

236 biominerals and synthetic 2-line ferrihydrite were fit using SIXPACK (Webb, 2005a).

237 Data were modeled using parameters of the EXAFS equation. Paths were generated using

238 the mineral scodorite in Feff9 (Rehr et al., 2010). EXAFS data were fit using a common

239 value of the parameter $\mathrm{E}_{0}$, which was allowed to float during optimization. The amplitude

240 reduction factor $\left(\mathrm{S}_{0}^{2}\right)$ was fixed at 0.85 (Foster et al., 1998; Paktunc et al., 2003).

241 For As(III), published models have typically contained an As-O shell at $\mathrm{R} \approx 1.7-$

$2421.8 \AA$, representing oxygen atoms surrounding a central As(III) atom. Arsenite is thought

243 to be bound to the ferrihydrite surface dominantly via a bidentate mononuclear complex

$244(\mathrm{R} \approx 2.9 \AA)$ and a bidentate binuclear complex $(\mathrm{R} \approx 3.4 \AA$ ) (Gao et al., 2013). We

245 consequently constructed a three shell model to capture these features. A first shell was

246 constructed with an As-O scattering path with $\mathrm{N}, \sigma^{2}$, and $\mathrm{R}$ allowed to float. To represent

247 Fe in surface complexes, two shells with As-Fe paths were constructed. In both paths, $\mathrm{N}$

248 was fixed whereas $R$ was allowed to float; $\sigma^{2}$ was allowed to float but was linked for both

249 paths. In addition, the amplitude of each path was modified by a fraction mononuclear ( $\mathrm{f}$ 
250 ), which was designed to allow for estimation of how much As was bound to these

251 coordination environments (e.g., the fraction of binuclear complexes is (1-f)).

252 For $\mathrm{As}(\mathrm{V})$, models have typically been fit by using, in addition to an As-O first

253 shell $(\mathrm{R} \approx 1.7 \AA)$, a single bidentate binuclear complex $(\mathrm{R} \approx 3.3 \AA)$ and an As-O-O

254 multiple scattering feature (Gao et al., 2013). However, fits to our spectra were not

255 improved by inclusion of a multiple scattering path. Therefore, we constructed a model

256 with a first shell containing As-O and As-Fe scattering paths with $\mathrm{N}, \sigma^{2}$, and $\mathrm{R}$ allowed to 257 float.

258

259 3. RESULTS

260 3.1. Properties of Iron Minerals

261 Micrographs (TEM) of environmental Fe(III) biomineral and synthetic 2-line

262 ferrihydrite samples are shown in Fig. 1. Differences in morphology are present between

263 environmental and synthetic samples. The environmental Fe(III) biomineral particles has

264 a ragged morphology similar to literature reports of other Fe(III) biominerals (Posth et

265 al., 2010), with particles sizes that range from approximately 50 to $200 \mathrm{~nm}$. This

266 morphology differs from synthetic 2-line ferrihydrite, which appears to be comprised of

267 regular aggregates of small ball-like masses.

268 The composition and physical properties of Fe mineral samples are shown in

269 Table 1. Environmental samples contained $19.7-36.1 \% \mathrm{Fe}(\mathrm{w} / \mathrm{w})$ and $8.2-11.1 \% \mathrm{C}$

$270(\mathrm{w} / \mathrm{w})$. Although there is considerable variability in the concentrations, there is neither

271 significant correlation between $\mathrm{Fe}$ and $\mathrm{C}$ concentrations, nor are there consistent seasonal

272 trends in the $\mathrm{Fe}$ or $\mathrm{C}$ content. There is, however, a positive correlation (data not shown; $p$ 
$273=0.02$ ) between surface area and Fe concentration, suggesting that iron (oxyhydr)oxides

274 are the dominant contributor to surface area. Zeta potential results for Fe(III) mineral

275 samples are all found to be negative at $\mathrm{pH}=7$. Environmental Fe(III) biominerals have a

276 more negative charge (ranging from approximately -20 to $-30 \mathrm{mV}$ ) than synthetic 2-line

277 ferrihydrite $(-10 \mathrm{mV})$. The mildly negative value for synthetic ferrihydrite indicates a

$278 \mathrm{pH}_{\mathrm{pzc}}<7$, which is lower than previous measurements of the point of zero charge $\left[\mathrm{pH}_{\mathrm{pzc}}\right.$

$279=7.0-7.5$ (Schwertmann and Fechter, 1982; Zhu et al., 2011)]. It is not clear what factors

280 in the preparation or measurement account for this discrepancy. Surface areas (BET

281 method) vary from $163-83 \mathrm{~m}^{2} \mathrm{~g}^{-1}$, slightly lower that the range previously reported for

282 natural iron minerals in a New Zealand creek (Childs et al., 1982).

283 The iron minerals were further characterized for mineralogy. X-ray diffraction

284 results (EA Fig. S2) indicate that our synthetic and environmental minerals contain

285 predominantly 2-line ferrihydrite, with quartz as the other phase observed $(<10 \%$

286 crystalline phases). Fe K-edge X-ray absorption spectroscopy (XAS) data are presented

287 in Fig. 2. From the normalized Fe XANES data, all spectra for Fe(III) mineral standards

288 and $\mathrm{Fe}(\mathrm{III})$ biominerals have similar adsorption edge positions (approximately $7128 \mathrm{eV}$ ).

289 For all samples, the highest FT magnitude is at $R \approx 2 \AA$, an interatomic distance

290 characteristic of Fe(III)-O bonding (Shannon, 1976).

$291 \quad$ Normalized Fe XANES and Fe EXAFS linear combination fitting (dashed lines in

292 Fig. 2) were performed, with results shown in Table 2. Arsenic K-edge spectra obtained

293 for Fe(III) mineral samples were with low and high concentrations of As (Table 3; Fe:As

294 ratios of $300: 1$ and 62.5:1, respectively). Using Fe(III) XANES, all samples contain a

$295100 \%$ contribution from poorly ordered Fe(III) minerals (consisting of either hydrous 
$296 \mathrm{Fe}(\mathrm{III})$ oxide or 2-line ferrihydrite), which is similar to what was seen from Fe EXAFS

297 for EnvFe_As(III). Although the fit EnvFe_As(V) primarily contains poorly ordered

$298 \mathrm{Fe}(\mathrm{III})$ oxides $(\sim 80-90 \%)$, the inclusion of a $\mathrm{Fe}(\mathrm{III})$ carboxylate siderophore complex

299 ( 10-20\%; labeled as Fe(III)-Rhiz in Fig. 2 and Table 2) improves the Fe EXAFS LCF.

300

301 3.2. Sorption of As to Iron Minerals

302 The sorption of $\mathrm{As}(\mathrm{V})$ and $\mathrm{As}(\mathrm{III})$ to synthetic 2-line ferrihydrite as a function of

303 time is shown in EA Fig. S3a and S3b, respectively. Sorbed concentration increased

304 rapidly in the first two hours after initial $\mathrm{As}(\mathrm{V})$ or $\mathrm{As}(\mathrm{III})$ introduction into the system,

305 with approximately $60 \%$ of the total sorption observed occurring within this time. At 48

306 hours, the sorbed concentration approached maximum values of approximately $1.8 \mu \mathrm{mol}$

$307 \mathrm{As} \mathrm{m}^{-2}$ and $4.0 \mu \mathrm{mol} \mathrm{As} \mathrm{m}^{-2}$ for $\mathrm{As}(\mathrm{V})$ and $\mathrm{As}(\mathrm{III})$, respectively, on synthetic 2-line

308 ferrihydrite for $\mathrm{As}(\mathrm{V})$ experiments. Similar rates of sorption were observed for $\mathrm{As}(\mathrm{V})$

309 sorption to environmental Fe(III) biominerals, with approximately $70 \%$ of total sorption

310 occurring within the first two hours after initial $\mathrm{As}(\mathrm{V})$ introduction and a maximum value

311 of $4.5 \mu \mathrm{mol} \mathrm{As} \mathrm{m}^{-2}$ reached after 48 hours. The concentration of As(III) sorbed to the

312 environmental $\mathrm{Fe}(\mathrm{III})$ biomineral sample approached an asymptote of $6.5 \mu \mathrm{mol} \mathrm{As} \mathrm{m}^{-2}$

313 after 48 hours of equilibration time. We therefore used 48 hours as an equilibration time

314 for concentration-dependent adsorption experiments for both $\mathrm{As}(\mathrm{V})$ and $\mathrm{As}(\mathrm{III})$, which is

315 consistent with previous equilibration times used for As isotherms (Raven et al., 1998).

316 Sorption of As to Fe(III) biominerals and synthetic 2-line ferrihydrite as a

317 function of dissolved As concentration is shown in Figs. 3 and 4, and EA Fig. S4. The

318 concentration of As associated with the surface increases with increasing dissolved 
319 concentration across the data range, with decreasing slope at high dissolved As

320 concentrations. The data are thus consistent with an L-type isotherm (Sposito, 2008), and

321 consequently the data were initially fit to both Freundlich and Langmuir sorption

322 isotherm models using a preprogramed spreadsheet with a non-linear solver (Bolster and

323 Hornberger, 2007). Based on goodness of fit, all data were modeled using the Freundlich

324 isotherm. For all data sets, fit parameters for the Freundlich model $\left(S=K_{f} C^{n}\right)$, where $S$

325 is sorbed concentration, $K_{f}$ is a sorption constant, $C$ is dissolved sorbate concentration,

326 and $n$ is an exponential sorption constant, are shown in Table 4 and 5.

327 The mass-normalized sorption of $\mathrm{As}(\mathrm{V})$ and As(III) is shown for environmental

328 and synthetic samples in Figs. 3a and 3b, respectively. Variability in sorption extent was

329 observed for both $\mathrm{As}(\mathrm{V})$ and $\mathrm{As}(\mathrm{III})$ data, with $\mathrm{As}(\mathrm{V})$ data having the highest variability

330 per mass of sorbent. Differences in sorption behavior are reflected by differences in the

331 Freundlich fitting parameters $K_{f}$ and $n$ (Table 4). For As(V), mass normalized sorption by

332 environmental minerals equals or exceeds that of ferrihydrite whereas As(III) on

333 ferrihydrite equals or exceeds those of environmental biominerals.

334 In Fig. 4a and EA Fig S4a, As(V) sorption isotherm data were normalized to BET

335 surface area. Fits for environmental Fe(III) biominerals resulted in $K_{f}$ and $n$ values that

336 were within model uncertainty. Consequently, these biominerals were fit with one

337 Freundlich isotherm (Table 5). At dissolved As concentrations greater than $300 \mu \mathrm{M}$,

338 environmental Fe(III) biominerals had a sorbed concentration of approximately 4.0 to 5.0

$339 \mu \mathrm{mol} \mathrm{As} \mathrm{m}^{-2}$, approximately 2.5 times greater than what was observed at a similar

340 dissolved As concentration range for synthetic 2-line ferrihydrite (sorbed As(V)

341 concentration of approximately 1.5 to $2.0 \mu \mathrm{mol} \mathrm{As} \mathrm{m}^{-2}$ ). 
343 Fig. S4b. All environmental Fe(III) biominerals samples contained sorbed As

344 concentrations that are within error of another. Interestingly, results with synthetic 2-line

345 ferrihydrite mirrored biominerals for all dissolved As(III) concentrations. Fits for

346 environmental Fe(III) biominerals and synthetic ferrihydrite resulted in $K_{f}$ and $n$ values

347 that were within model uncertainty for all but one sample date; thus, all BET normalized

348 isotherms were fit with one Freundlich model. Interestingly, at dissolved As

349 concentrations greater than $300 \mu \mathrm{M}$, sorbed As concentration ranges from 7.0 to $7.5 \mu \mathrm{mol}$

$350 \mathrm{~m}^{-2}$, which is approximately double the sorbed concentration observed for $\operatorname{As}(\mathrm{V})$

351 experiments.

352 The relative concentrations of $\mathrm{As}(\mathrm{III})$ and $\mathrm{As}(\mathrm{V})$ in $\mathrm{As}(\mathrm{III})$ sorption isotherm

353 experiments were determined by speciation analysis using UHPLC. For As(III)

354 isotherms, it was determined from selected samples that the aqueous As remaining in the

355 supernatant after a 48 hour equilibration time with the sorbent was quantitatively the

356 As(III) species (>97\% in all samples tested; data not shown). Speciation was also

357 determined for selected $\mathrm{As}(\mathrm{V})$ isotherm samples for both environmental $\mathrm{Fe}(\mathrm{III})$

358 biominerals and synthetic 2-line ferrihydrite, with $>99 \%$ of the total As in the As(V)

359 oxidation state.

$361 \quad$ 3.3. As Binding at Iron Mineral Surfaces

362 Arsenic K-edge X-ray absorption spectra are shown in Fig. 5. Normalized As 363 XANES data confirm the predominance of As(V) and As(III) in samples from As(V) and 364 As(III) isotherms, respectively. The As(V) absorption edge occurred at approximately 
$36511875.5 \mathrm{eV}$ for all $\mathrm{As}(\mathrm{V})$-loaded samples and the As(III) absorption edge is at 366 approximately $11871.8 \mathrm{eV}$ for all As(III)-loaded samples.

367 In the FTs of both $\mathrm{As}(\mathrm{V})$ and $\mathrm{As}(\mathrm{III})$ spectra, a large peak at $R=1.6-1.8 \AA$ is the

368 major feature, which corresponds to O surrounding As. Additional smaller peaks are seen

369 at larger $R$, features which have been previously interpreted as arising from scattering

370 from Fe or from multiple scattering phenomena. Fitting results for As EXAFS spectra are

371 shown in Table 3. For all samples, first shell As-O coordination numbers are near their

372 expected values for each oxyanion. EXAFS spectra of As(III) can be fit by two As-Fe

373 distances (corresponding to two surface complexation structures) whereas $\mathrm{As}(\mathrm{V})$ is

374 adequately fit with one As-Fe distance. For all spectra, fit parameters are generally within

375 program estimated uncertainties of each other for $\mathrm{As}(\mathrm{V})$ or $\mathrm{As}(\mathrm{III})$ sorbed onto

376 ferrihydrite and environmental samples. This correspondence is consistent with

377 similarities in the beat structure of the EXAFS spectra, which appear to be invariant for 378 each spectral set when superimposed (EA Fig. S5).

380 4. DISCUSSION

\section{4.1. Mineralogy of Iron Minerals}

382 Determining the affinity of Fe(III) biominerals for As is critical to advancing the 383 current understanding of its cycling in environmental systems and requires a detailed

384 understanding of their mineralogy and structure. Transmission electron micrographs (Fig.

385 1) indicate morphological differences between environmental $\mathrm{Fe}(\mathrm{III})$ biominerals and

386 synthetic $\mathrm{Fe}(\mathrm{III})$ minerals. We observed our environmental $\mathrm{Fe}(\mathrm{III})$ biominerals to have

387 ragged filamentous structures consistent to what was observed in Fe(III) microbial mats 
388 by Chan et al. (2009), who reported that the reported biominerals were primarily

389 attributable to common $\mathrm{Fe}(\mathrm{II})$ oxidizing organisms in the genera Leptothrix and

390 Gallionella. Zeta potential analysis (Table 1) revealed that all Fe(III) mineral samples

391 had negative charge at $\mathrm{pH}=7$, with environmental Fe(III) biominerals having more

392 negative charge. This result is consistent with the incorporation of biomass and

393 polysaccharides, which have been shown to decrease Fe(III) mineral points of zero

394 charge (Mikutta et al., 2014), into our environmental Fe(III) minerals.

395 X-ray diffraction results indicate 2-line ferrihydrite as the predominant $\mathrm{Fe}$ (III)

396 mineral phase present in all environmental $\mathrm{Fe}(\mathrm{III})$ biomineral samples. These results are

397 roughly consistent with XAS linear combination fits, which suggest the predominant

398 presence of poorly crystalline oxides in all samples with the possible presence of a minor

399 fraction of organic iron complexes in $\operatorname{As}(\mathrm{V})$ bearing samples. Taken as whole, the

400 mineralogy of our system agrees well to previous studies showing $\mathrm{Fe}$ (III) minerals

401 produced by Fe(II) oxidizing bacteria in many environments consist predominately of a

402 ferrihydrite-like phase (Ferris, 2005; Duckworth et al., 2009; Cismasu et al., 2011;

403 Hohmann et al., 2011; Toner et al., 2012).

404

$405 \quad 4.2$ Sorption of As to Fe Minerals

406 It is instructive to compare of mass-normalized sorption data to previous studies.

407 We observed that the As(III) sorbed concentration to synthetic 2-line ferrihydrite at $\mathrm{pH}=$ 4087 was approximately $1100 \mu \mathrm{mol} \mathrm{g}^{-1}$ (Fig. 4). This value is somewhat less the ca. 1500

$409 \mu \mathrm{mol} \mathrm{g}{ }^{-1}$ observed by Dixit and Hering (2003) at their highest concentrations, but is

410 higher than the maximum value of $513 \mu \mathrm{mol} \mathrm{g}^{-1}$ reported by Pierce and Moore (1982) at 
$411 \mathrm{pH}=7$. Our maximum $\mathrm{As}(\mathrm{V})$ sorbed concentration $\left(\mathrm{ca} .400 \mu \mathrm{mol} \mathrm{g}^{-1}\right)$ is lower than the

412 maximum $\mathrm{pH}=7$ value of approximately $1100 \mu \mathrm{mol} \mathrm{g}^{-1}$ reported by Dixit and Hering

413 (2003), but agrees well with the $\mathrm{pH}=7$ maximum of $454 \mu \mathrm{mol} \mathrm{g}^{-1}$ reported by Pierce and

414 Moore (1982). The observed difference in As sorption may be to be due to differences in

415 experimental setup or mineral properties in individual studies. For biogenic minerals,

416 these results are consistent with a field study that found biogenic Fe(III) (oxyhydr)oxides

417 formed in a contaminated mining environment to have a large affinity for As (Keim,

418 2011). It should also be noted that biogenic oxides have been shown to have a lower

419 affinity for $\mathrm{As}(\mathrm{V})$ than iron-based commercial filter material and to reduce efficiency of

420 these filters (Kleinert et al, 2011) .

421 For both $\mathrm{As}(\mathrm{V})$ and As(III), surface area normalization effectively accounted for 422 the variation in reactivity of environmental $\mathrm{Fe}(\mathrm{III})$ biominerals. This outcome is perhaps 423 non-intuitive because the structure and morphology of biominerals can vary temporally,

424 as formation process may be controlled by environmental factors, such as groundwater

425 flow rates, temperature, aquatic chemical conditions, and microbial community 426 composition. In our data, this variability manifests itself in a range of compositions 427 (including iron and carbon) and surface areas for samples collected at different times. The 428 fact that normalization by surface area effectively accounts for this variability suggests 429 that the area of exposed Fe surfaces is the dominating factor in controlling sorption of 430 biogenic (oxyhydr)oxides, as it typically is for abiotic minerals of the same phase 431 (Goldberg and Johnston, 2000; Dixit and Hering, 2003; Sherman and Randall, 2003).

432 Surface area normalization of $\mathrm{As}(\mathrm{V})$ and $\mathrm{As}(\mathrm{III})$ isotherm data resulted in 433 different trends in the data sets for each species. All tested environmental $\mathrm{Fe}$ (III) 
434 biominerals were observed to sequester similar concentrations of $\mathrm{As}(\mathrm{V})$ (approximately

4354.0 to $5.0 \mu \mathrm{mol} \mathrm{As} \mathrm{m}^{-2}$ ), such that all environmental $\mathrm{Fe}(\mathrm{III})$ biomineral data were fit 436 accurately to the same sorption model $(\mathrm{E}=0.979)$. As(III) sorption data showed a similar

437 trend, although to a greater sorption extent, among environmental Fe(III) biominerals;

438 however, both environmental Fe(III) biomineral and synthetic 2-line ferrihydrite sorption

439 data converged effectively to one model $(\mathrm{E}=0.972)$. This result is different than what

440 was observed for the $\mathrm{As}(\mathrm{V})$ data, as environmental $\mathrm{Fe}(\mathrm{III})$ biominerals were found to sorb

$441 \mathrm{As}(\mathrm{V})$ to approximately three times the extent that was observed for synthetic 2-line

442 ferrihydrite.

\section{4.3 Surface Binding of As to Fe Mineral Surfaces}

$444 \quad$ For model fits for all As samples, first shell coordination numbers (Table 3) were

445 near those expected for sorbed arsenate and arsenite. In addition, As-O interatomic

446 distances $(R=1.76-1.77$ and $1.67-1.68 \AA$; Table 3$)$ are consistent with known bond

447 distances for As(III) and As(V), respectively. These results, coupled with XANES

448 spectra, suggest that As on the surface remains in its initial oxidation state (section 3.3).

449 This speciation behavior is consistent with the aqueous speciation data that indicated that

450 dissolved As also remains in its initial oxidation state (section 3.2). Furthermore, As K-

451 edge EXAFS spectra for both As(V) and As(III) (cf. overlain spectra in EA Fig. S5) show

452 that the beat structure of spectra are similar for all samples, suggesting that binding

453 structure is the same for each As species for synthetic and environmental samples, and is

454 invariant with concentration for environmental samples. Possible reasons for the

455 difference in the extent in $\operatorname{As}(\mathrm{V})$ sorption, despite the similarity in the structure of the 
456 binding environment for synthetic and biogenic minerals (as determined by EXAFS), are 457 discussed in section 4.4.

458 Previous studies employing As K-edge EXAFS have shown As(III) to bind to

459 synthetic 2-line ferrihydrite primarily through two bidentate inner-sphere complexation 460 structures. Based on this structural model, our fits (Table 3 and Fig. 5) yield a 461 mononuclear species with an As-Fe interatomic distance of $R=2.88-2.90 \AA$ and a 462 binuclear species with an As-Fe distance of $R=3.38-3.39 \AA$. These results are within 463 error of previous EXAFS derived interatomic distances; however, coordination numbers 464 from these studies (Ona-Nguema et al, 2005; Voegelin et al., 2007; Gao et al., 2013) 465 suggest a prevalence of mononuclear surface structures whereas our results suggest a near 466 even distribution of monodentate and bidentate complexes $(f=0.5 \pm 0.2$ for all samples). 467 Previous EXAFS studies performed at similar As/Fe molar ratios, $0.016 \mathrm{As} / \mathrm{Fe}$, 468 have shown that $\mathrm{As}(\mathrm{V})$ sorbs predominately through an inner-sphere corner sharing 469 bidentate binuclear complex (Waychunas et al., 1993; Gao et al., 2013), although outer 470 sphere complexes have been identified on hematite (Catalano et al., 2008). In a scenario 471 where all $\mathrm{As}(\mathrm{V})$ is sorbed as bidentate binuclear complexes, $N=2$ whereas the 472 coordination number would approach 0 for a predominantly outer-sphere complexes. Our 473 modeled coordination numbers $(N=1-2 \pm 3)$ are poorly constrained, and do not allow for 474 discrimination of the distribution of inner- and outer-sphere complexes. We note that 475 other approaches (e.g., surface complexation modeling) also are unable to definitively 476 distinguish between outer-sphere and bidentate binuclear complexes (Fukushi and 477 Sverjensky, 2007). We thus assert that our results are consistent with the presence of 478 bidentate binuclear complexes but do not preclude the presence of outer-sphere species. 
480 4.4 Why do environmental Fe(III) biominerals sorb more As(V) than synthetic $481 \quad$ minerals?

482 Although all As(III) sorption data converged when normalized to surface area for 483 all minerals tested, environmental Fe(III) minerals sorbed approximately three times $484 \mathrm{As}(\mathrm{V})$ at their maximum loading as compared to the synthetic ferrihydrite. We emphasize 485 that EXAFS spectroscopy yields no detectable difference in As surface complexation 486 structure for different Fe minerals (Table 3 and EA Fig. 5A). Although we lack direct

487 evidence of the factors that drive changes in the extent of $\mathrm{As}(\mathrm{V})$ binding, we speculate 488 that either changes in the nature of surface sites or in the nature of surface complexation 489 structures are primary factors.

$490 \quad$ Firstly, As(V) has been shown to sorb predominately through corner sharing sites 491 whereas As(III) sorbs through both corner and edge sharing complexes (Gao et al., 2013). 492 Although lower surface areas were measured for the environmental Fe(III) biomineral 493 samples, we expect that the environmental Fe(III) biominerals generally have smaller 494 domain sizes compared to synthetic 2-line ferrihydrite (Cismasu et al., 2011). Based on 495 the small domain size, we speculate that the environmental Fe(III) biominerals may 496 contain more sites for corner sharing complexes. Alternately, it is possible that 497 environmental minerals may sorb more outer-sphere complexes. The close association of 498 organic matter may result in physicochemical changes to the interfacial region (e.g., 499 change to the ordering, and thus activity of water) that may facilitate accumulation of 500 outer-sphere complexes (Dzombak and Morel, 1990; Fukushi and Sverjenski, 2007). 501 However, to further explore these explanations, careful determination of domain size 
502 (e.g., paired distribution function analysis or high resolution TEM) (Michel et al., 2007b)

503 is needed to better elucidate the drivers of the differences in sorption reactivity of As

504 species on environmental biominerals. Finally, because our environmental biominerals

505 contain $8.2-11.1 \%$ carbon, it is possible that As-Fe-organic ternary complexes (Sharma et

506 al., 2010; Mikutta and Kretzschmar, 2011) may also contribute to As binding to

507 biominerals. Although our XAS data does not support the presence of these species,

508 spectroscopic data may not be adequately sensitive to preclude the presence of a fraction

509 of ternary complexes.

510

\section{5. CONCLUSIONS}

512 Our results suggest that environmental Fe(III) biominerals are chemically and 513 mineralogically similar to synthetic ferrihydrite. Although we observed variability in

514 composition and As-sorption reactivity (on a per mass basis), surface area normalization

515 effectively accounts for the variability of environmental biominerals. In terms of

516 reactivity, the environmental Fe(III) biominerals sorb As(III) to the same extent as

517 synthetic ferrihydrite. However, despite their structural similarity, environmental $\mathrm{Fe}$

518 minerals sorb approximately three times more $\mathrm{As}(\mathrm{V})$ (on a surface area basis) than

519 ferrihydrite. Interestingly, analysis of K-edge As EXAFS does not reveal significant

520 differences in the binding mechanism for $\mathrm{As}(\mathrm{IIII})$ or $\mathrm{As}(\mathrm{V})$ on the different minerals.

521 The results have significant implications for the transport of As. In anoxic

522 groundwater, both As and Fe are typically found in their reduced states [As(III) and

$523 \mathrm{Fe}(\mathrm{II})]$ (Smedley and Kinniburgh, 2013). Upon gradual aeration, redox gradients that

524 promote formation of Fe(III) biominerals may develop (Emerson et al., 2010). Our results 
525 suggest $\mathrm{As}(\mathrm{III})$ would be retained preferentially [as compared to $\mathrm{As}(\mathrm{V})$ ] by these $\mathrm{Fe}(\mathrm{III})$

526 deposits at circumneutral $\mathrm{pH}$; however, if $\mathrm{As}(\mathrm{V})$ is produced by oxidation, its retention is

527 more favorable than would be predicted based on the reactivity of synthetic ferrihydrite.

528 Biominerals may thus be important regulators of transport where contaminated

529 groundwater discharges into slow moving waters (particularly because imbedding of

530 minerals in biofilms may reduce colloidal transport of Fe minerals) or possibly near the

531 roots of plants with aerenchyma (including rice) (Mandal and Suzuki, 2002; Meharg and

532 Zhao, 2012; Smedley and Kinniburgh, 2013). In addition, our results suggest that

533 biominerals may be useful in treatment of contaminated water by designed remediation

534 systems with controlled aeration. Future work could seek to quantify how the observed

535 structural properties and reactivity of biominerals manifest themselves in terms of

536 contaminant desorption and long-term sequestration potential.

538 Electronic Annex. Supplementary data associated with this article can be found in the

539 online version, at doi:XXXX

540 Acknowledgements. We are grateful for support received from the National Science

541 Foundation Geobiology and Low-Temperature Geochemistry Program (award numbers

5421255158 and 1324912). We also thank Megan Andrews, Andrew Whitaker, Nelson

543 Rivera, Jongho Won, Ryan Davis, Matthew Lattimer, and Jeff Maske for their assistance.

544 This work was performed in part at the Analytical Instrumentation Facility (AIF) at North

545 Carolina State University, which is supported by the State of North Carolina and the

546 National Science Foundation (award number ECCS-1542015). The AIF is a member of

547 the North Carolina Research Triangle Nanotechnology Network (RTNN), a site in the 
548 National Nanotechnology Coordinated Infrastructure (NNCI). Use of the Stanford

549 Synchrotron Radiation Lightsource, SLAC National Accelerator Laboratory, is supported

550 by the U.S. Department of Energy, Office of Science, and Office of Basic Energy

551 Sciences under Contract No. DE-AC02-76SF00515.




\section{REFERENCES}

Bauer, M., Blodau, C., 2006. Mobilization of arsenic by dissolved organic matter from iron oxides, soils and sediments. Science of the Total Environment 354, 179-190.

Bolster, C.H., Hornberger, G.M., 2007a. On the use of linearized Langmuir equations. Soil Science Society of America Journal 71, 1796-1806.

Borch, T., Kretzschmar, R., Kappler, A., Cappellen, P.V., Ginder-Vogel, M., Voegelin, A., Campbell, K., 2009. Biogeochemical redox processes and their impact on contaminant dynamics. Environmental Science \& Technology 44, 15-23.

Bowell, R., 1994. Sorption of arsenic by iron oxides and oxyhydroxides in soils. Applied Geochemistry 9, 279-286.

Brammer, H., Ravenscroft, P., 2009. Arsenic in groundwater: a threat to sustainable agriculture in South and South-east Asia. Environment International 35, 647-654.

Catalano, J.G., Park, C., Fenter, P., Zhang, Z., 2008. Simultaneous inner-and outer-sphere arsenate adsorption on corundum and hematite. Geochimica et Cosmochimica Acta 72, 1986-2004.

Chan, C.S., Fakra, S.C., Edwards, D.C., Emerson, D., Banfield, J.F., 2009. Iron oxyhydroxide mineralization on microbial extracellular polysaccharides. Geochimica et Cosmochimica Acta 73, 3807-3818.

Childs, C., Downes, C., Wells, N., 1982. Hydrous iron oxide minerals with short range order deposited in a spring/stream system, Tongariro National Park, New Zealand. Soil Research 20, 119-129.

Cismasu, A.C., Michel, F.M., Stebbins, J.F., Levard, C., Brown, G.E., 2012. Properties of impurity-bearing ferrihydrite I. Effects of $\mathrm{Al}$ content and precipitation rate on the structure of 2-line ferrihydrite. Geochimica et Cosmochimica Acta 92, 275-291.

Cismasu, A.C., Michel, F.M., Tcaciuc, A.P., Tyliszczak, T., Brown Jr, G.E., 2011. Composition and structural aspects of naturally occurring ferrihydrite. Comptes Rendus Geoscience 343, 210-218.

Cornell, R.M., Schwertmann, U., 2003. The iron oxides: structure, properties, reactions, occurrences and uses. Wiley-VCH. Weinheim, DE.

Das, S., Essilfie-Dughan, J., Hendry, M.J., 2014. Arsenate partitioning from ferrihydrite to hematite: Spectroscopic evidence. American Mineralogolist 99, 749-754.

Dixit, S., Hering, J.G., 2003. Comparison of Arsenic(V) and Arsenic(III) Sorption onto Iron Oxide Minerals: Implications for Arsenic Mobility. Environmental Science \& Technology 37, 4182-4189.

Duckworth, O.W., Holmström, S.J., Peña, J., Sposito, G., 2009. Biogeochemistry of iron oxidation in a circumneutral freshwater habitat. Chemical Geology 260, 149-158.

Dzombak, D.A., Morel, F.M., 1990. Surface complexation modeling: hydrous ferric oxide. John Wiley \& Sons.

Emerson, D., Fleming, E.J., McBeth, J.M., 2010. Iron-oxidizing bacteria: an environmental and genomic perspective. Annual review of microbiology 64, 561583.

Emerson, D., Weiss, J.V., 2004. Bacterial iron oxidation in circumneutral freshwater habitats: findings from the field and the laboratory. Geomicrobiology Journal 21, 405-414. 
Fendorf, S., Eick, M.J., Grossl, P., Sparks, D.L., 1997. Arsenate and chromate retention mechanisms on goethite. 1. Surface structure. Environmental Science \& Technology 31, 315-320.

Ferris, F.G., 2005. Biogeochemical Properties of Bacteriogenic Iron Oxides. Geomicrobiology Journal 22, 79-85.

Ferris, F.G., Hallberg, R.O., Lyvén, B., Pedersen, K., 2000. Retention of strontium, cesium, lead and uranium by bacterial iron oxides from a subterranean environment. Applied Geochemistry 15, 1035-1042.

Foster, A.L., Brown, G.E., Tingle, T.N., Parks, G.A., 1998. Quantitative arsenic speciation in mine tailings using $\mathrm{X}$-ray absorption spectroscopy. American Mineralogist 83, 553-568.

Fukushi, K., Sverjensky, D.A., 2007. A predictive model (ETLM) for arsenate adsorption and surface speciation on oxides consistent with spectroscopic and theoretical molecular evidence. Geochimica et Cosmochimica Acta 71, 3717-3745.

Fuller, C.C., Davis, J.A., Waychunas, G.A. 1993. Surface chemistry of ferrihydrite: Part 2. Kinetics of arsenate adsorption and coprecipitation. Geochimica et Cosmochimica Acta 57, 2271-2282.

Gao, X., Root, R.A., Farrell, J., Ela, W., Chorover, J., 2013. Effect of silicic acid on arsenate and arsenite retention mechanisms on 6-L ferrihydrite: A spectroscopic and batch adsorption approach. Applied Geochemistry 38, 110-120.

Gault, A.G., Ibrahim, A., Langley, S., Renaud, R., Takahashi, Y., Boothman, C., Lloyd, J.R., Clark, I.D., Ferris, F.G., Fortin, D., 2011. Microbial and geochemical features suggest iron redox cycling within bacteriogenic iron oxide-rich sediments. Chemical Geology 281, 41-51.

Giménez, J., Martinez, M., de Pablo, J., Rovira, M., Duro, L., 2007. Arsenic sorption onto natural hematite, magnetite, and goethite. Journal of Hazardous Materials $141,575-580$.

Goldberg, S., 2002. Competitive adsorption of arsenate and arsenite on oxides and clay minerals. Soil Science Society of America Journal 66, 413-421.

Goldberg, S., Johnston, C.T., 2001. Mechanisms of arsenic adsorption on amorphous oxides evaluated using macroscopic measurements, vibrational spectroscopy, and surface complexation modeling. Journal of colloid and Interface Science 234, 204-216.

Grafe, M., Eick, M.J., Grossl, P.R., Saunders, A.M., 2002. Adsorption of arsenate and arsenite on ferrihydrite in the presence and absence of dissolved organic carbon, Journal of Environmental Quality 31, 1115-1123.

Hao, L., Guo, Y., Byrne, J.M., Zeitvogel, F., Schmid, G., Ingino, P., Li, J., Neu, T.R., Swanner, E.D., Kappler, A., Obst, M., 2016. Binding of heavy metal ions in aggregates of microbial cells, EPS and biogenic iron minerals measured in-situ using metal- and glycoconjugates-specific fluorophores. Geochimica Cosmochimica Acta, 180, 66-96.

Harrington, J.M., Parker, D.L., Bargar, J.R., Jarzecki, A.A., Tebo, B.M., Sposito, G., Duckworth, O.W., 2012. Structural dependence of Mn complexation by siderophores: donor group dependence on complex stability and reactivity. Geochimica et Cosmochimica Acta 88, 106-119. 
Hohmann, C., Morin, G., Ona-Nguema, G., Guigner, J.-M., Brown, G.E., Kappler, A., 2011. Molecular-level modes of As binding to Fe (III)(oxyhydr) oxides precipitated by the anaerobic nitrate-reducing Fe (II)-oxidizing Acidovorax sp. strain BoFeN1. Geochimica et Cosmochimica Acta 75, 4699-4712.

Hohmann, C., Winkler, E., Morin, G., Kappler, A., 2009. Anaerobic Fe (II)-oxidizing bacteria show As resistance and immobilize As during $\mathrm{Fe}$ (III) mineral precipitation. Environmental Science \& Technology 44, 94-101.

Jain, A. and Loeppert, R.H., 2000. Effect of competing anions on the adsorption of arsenate and arsenite by ferrihydrite. Journal of Environmental Quality 29, 14221430.

Jambor, J.L., Dutrizac, J.E., 1998. Occurrence and constitution of natural and synthetic ferrihydrite, a widespread iron oxyhydroxide. Chemical Reviews 98, 2549-2586.

Keim, C. N., 2011. Arsenic in biogenic iron minerals from a contaminated environment. Geomicrobiology Journal, 28(3), 242-251.

Kelly, S.D., Hesterberg, D., Ravel, B., 2008. Analysis of Soils and Minerals Using X-ray Absorption Spectroscopy, in: Ulery, A.L., Drees, L.R. (Eds.), Methods of Soil Analysis Soil Science Society of America, Madison, WI.

Kikuchi, S., Makita, H., Takai, K., Yamaguchi, N., Takahashi, Y., 2014. Characterization of biogenic iron oxides collected by the newly designed liquid culture method using diffusion chambers. Geobiology 12, 133-145.

Kim, M.J., Nriagu, J., 2000. Oxidation of arsenite in groundwater using ozone and oxygen. Science of the total environment 247, 71-79.

Kim, N. H., Mason, C. C., Nelson, R. G., Afton, S. E., Essader, A. S., Medlin, J. E., Levine, K. E., Hoppin, J. A., Lin, C., Knowler, W. C., \& Sandler, D. P. (2013). Arsenic Exposure and Incidence of Type 2 Diabetes in Southwestern American Indians. American Journal of Epidemiology, 177, 962-969.

Kleinert, S., Muehe, E.M., Posth, N.R., Dippon, U., Daus, B., Kappler, A., 2011. Biogenic Fe (III) minerals lower the efficiency of iron-mineral-based commercial filter systems for arsenic removal. Environmental science \& technology 45, 75337541.

Klute, A., 1965. Methods of Soil Analysis. Part 1. Physical and Mineralogical Properties, Including Statistics of Measurement and Sampling. American Society of Agronomy, Soil Science Society of America, Madison, WI.

Mandal, B.K., Suzuki, K.T., 2002. Arsenic round the world: a review. Talanta 58, 201235.

Meharg, A.A., Zhao, F.-J., 2012. Arsenic and rice. Springer, Dordrecht, NL.

Michel, F., Ehm, L., Liu, G., Han, W., Antao, S., Chupas, P., Lee, P., Knorr, K., Eulert, H., Kim, J., 2007a. Similarities in 2-and 6-line ferrihydrite based on pair distribution function analysis of X-ray total scattering. Chemistry of Materials 19, 1489-1496.

Michel, F.M., Ehm, L., Antao, S.M., Lee, P.L., Chupas, P.J., Liu, G., Strongin, D.R., Schoonen, M.A., Phillips, B.L., Parise, J.B., 2007b. The structure of ferrihydrite, a nanocrystalline material. Science 316, 1726-1729.

Mikutta, C., Kretzschmar, R., 2011. Spectroscopic Evidence for Ternary Complex Formation between Arsenate and Ferric Iron Complexes of Humic Substances. Environ. Sci. Technol. 45, 9550-9557. 
Mikutta, R., Lorenz, D., Guggenberger, G., Haumaier, L., Freund, A., 2014. Properties and reactivity of Fe-organic matter associations formed by coprecipitation versus adsorption: Clues from arsenate batch adsorption. Geochimica et Cosmochimica Acta 144, 258-276.

Milstein, L. S., Essader, A., Pellizzari, E. D., Fernando, R. A., Raymer, J. H., Levine, K. E., \& Akinbo, O. (2003). Development and application of a robust speciation method for determination of six arsenic compounds present in human urine. Environmental Health Perspectives, 111, 293-296.

Mohan, D., Pittman Jr, C.U., 2007. Arsenic removal from water/wastewater using adsorbents - a critical review. Journal of Hazardous materials 142, 1-53.

Muehe, E.M., Scheer, L., Daus, B., Kappler, A., 2013. Fate of Arsenic during Microbial Reduction of Biogenic versus Abiogenic As-Fe(III)-Mineral Coprecipitates. Environmental Science \& Technology 47, 8297-8307.

Muehe, E.M., Kappler A., 2014. Arsenic mobility and toxicity in the environment - a review on biogeochemistry, health and socio-economic effects, remediation and future predictions. Environmental Chemistry, 5, 483-495.

Newville, M., 2001. IFEFFIT: interactive XAFS analysis and FEFF fitting. Journal of synchrotron radiation $8,322-324$.

O’day, P.A., Rivera, N., Root, R., Carroll, S.A., 2004. X-ray absorption spectroscopic study of Fe reference compounds for the analysis of natural sediments. American Mineralogist 89, 572-585.

Ona-Nguema, G., Morin, G., Juillot, F., Calas, G., Brown, G., 2005. EXAFS analysis of arsenite adsorption onto two-line ferrihydrite, hematite, goethite, and lepidocrocite. Environmental Science \& Technology 39, 9147-9155.

Paktunc, D., Foster, A., Laflamme, G., 2003. Speciation and characterization of arsenic in Ketza River mine tailings using X-ray absorption spectroscopy. Environmental Science \& Technology 37, 2067-2074.

Pierce, M.L., and Moore, C.B., 1982. Adsorption of arsenite and arsenate on amorphous iron hydroxide. Water Research 16, 1247-1253.

Posth, N.R., Huelin, S., Konhauser, K.O., Kappler, A., 2010. Size, density and composition of cell-mineral aggregates formed during anoxygenic phototrophic $\mathrm{Fe}(\mathrm{II})$ oxidation: Impact on modern and ancient environments. Geochimica et Cosmochimica Acta 74, 3476-3493.

Posth, N., Canfield, D.E., Kappler, A., 2014. Biogenic Fe(III) minerals: from formation to diagenesis and preservation in the rock record. Earth-Science Reviews, 135, 103-121.

Ravel, B., Newville, M., 2005. ATHENA, ARTEMIS, HEPHAESTUS: data analysis for X-ray absorption spectroscopy using IFEFFIT. Journal of synchrotron radiation 12, 537-541.

Raven, K.P., Jain, A., Loeppert, R.H., 1998. Arsenite and arsenate adsorption on ferrihydrite: kinetics, equilibrium, and adsorption envelopes. Environmental Science \& Technology 32, 344-349.

Redman, A.D., Macalady, D.L., Ahmann, D., 2002. Natural organic matter affects arsenic speciation and sorption onto hematite. Environmental Science \& Technology 36, 2889-2896. 
Rehr, J.J., Kas, J.J., Vila, F.D., Prange, M.P., Jorissen, K., 2010. Parameter-free calculations of X-ray spectra with FEFF9. Physical Chemistry Chemical Physics $12,5503-5513$.

Roden, E.E., McBeth, J.M., Blöthe, M., Percak-Dennett, E.M., Fleming, E.J., Holyoke, R.R., Luther III, G.W., Emerson, D., Schieber, J., 2012. The microbial ferrous wheel in a neutral $\mathrm{pH}$ groundwater seep. The microbial ferrous wheel: iron cycling in terrestrial, freshwater, and marine environments, 199.

Schadler, S., Burkhardt, C., Hegler, F., Straub, K.L., Miot, J., Benzerara, K., Kappler, A., 2009. Formation of Cell-Iron-Mineral Aggregates by Phototrophic and NitrateReducing Anaerobic Fe(II)-Oxidizing Bacteria. Geomicrobiology Journal 26, 93 103.

Schmid, G., Zeitvogel, F., Hao, L., Ingino, P., Floetenmeyer, M., Stierhof, Y.D., Schroeppel, B., Burkhardt, C., Kappler, A., Obst, M., 2014. 3D analysis of bacterial cell-(iron)mineral aggregates formed by the nitrate-reducing $\mathrm{Fe}$ (II) oxidizing Acidovorax sp. BoFeN1 using complementary microscopy tomography approaches. Geobiology, 12, 340-361.

Schwertmann, U., \& Fechter, H. 1982. The point of zero charge of natural and synthetic ferrihydrites and its relation to adsorbed silicate. Clay Minerals, 17, 471-476.

Shannon, R.T., 1976. Revised effective ionic radii and systematic studies of interatomic distances in halides and chalcogenides. Acta Crystallographica Section A: Crystal Physics, Diffraction, Theoretical and General Crystallography 32, 751-767.

Sharma, P., Ofner, J., Kappler, A., 2010. Formation of Binary and Ternary Colloids and Dissolved Complexes of Organic Matter, Fe and As. Environ. Sci. Technol. 44, 4479-4485.

Sherman, D.M., Randall., S.R., 2003. Surface complexation of arsenic(V) to iron(III) (hydr)oxides: Structural mechanism from ab initio molecular geometries and EXAFS spectroscopy. Geochimica et Cosmochimica Acta 67, 4223-4230.

Smedley, P., Kinniburgh, D.G., 2013. Arsenic in groundwater and the environment, Essentials of Medical Geology. Springer, pp. 279-310.

Smedley, P.L., Kinniburgh, D.G., 2002. A review of the source, behaviour and distribution of arsenic in natural waters. Applied Geochemistry 17, 517-568.

Sposito, G., 2008. The chemistry of soils. Oxford university press.

Toner, B.M., Berquó, T.S., Michel, F.M., Sorensen, J.V., Templeton, A.S., Edwards, K.J., 2012. Mineralogy of iron microbial mats from Loihi Seamount. The microbial ferrous wheel: iron cycling in terrestrial, freshwater, and marine environments, 181.

Voegelin, A., Weber, F.A., Kretzshamar, R., 2007. Distribution and speciation of arsenic around roots in a contaminated riparian floodplain soil: Micro-XRF element mapping and EXAFS spectroscopy. Geochimica et Cosmochimica Acta 71, 58045820.

Waychunas, G., Rea, B., Fuller, C., Davis, J., 1993. Surface chemistry of ferrihydrite: Part 1. EXAFS studies of the geometry of coprecipitated and adsorbed arsenate. Geochimica et Cosmochimica Acta 57, 2251-2269.

Webb, S., 2005a. SIXpack: a graphical user interface for XAS analysis using IFEFFIT. Physica Scripta 2005, 1011. 
Webb, S.M., 2005b. SIXPACK: A graphical user interface for XAS analysis using IFEFFIT. Phys. Scr., 1011-1014.

Welch A., Westjohn, D.B., Helsel, D.R., Wanty, R.B, 2000. Arsenic in ground water of the United States: occurrence and geochemistry. Ground water 38, 589-604.

Wilkie, J.A., Hering, J.G., 1996. Adsorption of arsenic onto hydrous ferric oxide: effects of adsorbate/adsorbent ratios and co-occurring solutes. Colloids and Surfaces A: Physicochemical and Engineering Aspects 107, 97-110.

Xiu, W., Guo, H., Liu, Q., Liu, Z., \& Zhang, B., 2015. Arsenic removal and transformation by Pseudomonas sp. strain GE-1-induced ferrihydrite: coprecipitation versus adsorption. Water, Air, \& Soil Pollution, 226(6), 1-14.

Zhu, J., Pigna, M., Cozzolino, V., Caporale, A.G., Violante, A., 2011. Sorption of arsenite and arsenate on ferrihydrite: Effect of organic and inorganic ligands. Journal of hazardous materials 189, 564-571. 
Table 1. Composition and properties of synthetic 2-line ferrihydrite and environmental $\mathrm{Fe}(\mathrm{III})$ biominerals. Unless specified, reported values have an error estimated at approximately $10 \%$.

\begin{tabular}{cccccc}
\hline Sorbate & Sample & Surface Area $\left(\mathbf{m}^{2} \mathbf{g}^{-1}\right)$ & $\mathbf{F e}(\% \mathbf{w} / \mathbf{w})$ & $\mathbf{C}(\% \mathbf{w} / \mathbf{w})$ & $\zeta$-potential $(\mathbf{m V})$ \\
\hline As(V) & Synthetic & 210 & 50 & --- & $-10 \pm 8$ \\
& Env_6/19/15 & 132 & 36.1 & 8.2 & $-32 \pm 5$ \\
& Env_8/22/15 & 83 & 19.7 & 10.4 & $-31 \pm 5$ \\
& Env_1/8/16 & 156 & 35.3 & 9.7 & $-32 \pm 4$ \\
$\operatorname{As}(\mathrm{III})$ & Synthetic & 210 & 50 & --- & $-10 \pm 8$ \\
& Env_9/11/15 & 86 & 28.7 & 11.1 & $-21 \pm 5$ \\
& Env_1/8/16 & 159 & 35.3 & 8.7 & $-32 \pm 4$ \\
& Env_2/12/16 & 163 & 33.9 & 9.5 & $-22 \pm 8$ \\
\hline
\end{tabular}


Table 2. Linear combination fitting results for biomineral samples using X-ray absorption spectroscopy data collected at the Stanford Synchrotron Radiation Lightsource. Linear combination fitting was performed in SIXPACK and normalized to $100 \%$, with raw fits summing to $100 \pm 1 \%$ and $100 \pm 30 \%$ for XANES and EXAFS spectra, respectively.

\begin{tabular}{|c|c|c|c|}
\hline Sample & Standard & $\begin{array}{c}\% \\
\text { contribution }\end{array}$ & R-factor \\
\hline \multicolumn{4}{|c|}{ XANES Spectra Linear Combination Fits } \\
\hline EnvFe_High As(V) & Hydrous Fe(III) oxide & $100 \pm 1$ & 0.00014 \\
\hline EnvFe_Low As(V) & Hydrous Fe(III) oxide & $100 \pm 1$ & 0.00067 \\
\hline EnvFe_High As(III) & Ferrihydrite & $100 \pm 2$ & 0.00042 \\
\hline EnvFe_Low As(III) & Ferrihydrite & $100 \pm 1$ & 0.00002 \\
\hline \multicolumn{4}{|c|}{ EXAFS Spectra Linear Combination Fits } \\
\hline \multirow[t]{3}{*}{ EnvFe_High As(V) } & $\mathrm{Fe}(\mathrm{III})-\mathrm{Rhiz}$ & $10 \pm 2$ & 0.024 \\
\hline & Hydrous Fe(III) oxide & $40 \pm 10$ & \\
\hline & Ferrihydrite & $50 \pm 20$ & \\
\hline \multirow[t]{3}{*}{ EnvFe_Low As(V) } & Fe(III)-Rhiz & $18 \pm 4$ & 0.013 \\
\hline & Hydrous Fe(III) oxide & $50 \pm 10$ & \\
\hline & Ferrihydrite & $36 \pm 8$ & \\
\hline \multirow[t]{2}{*}{ EnvFe_High As(III) } & Hydrous Fe(III) Oxide & $49 \pm 10$ & 0.050 \\
\hline & Ferrihydrite & $50 \pm 10$ & \\
\hline EnvFe_Low As(III) & $\begin{array}{l}\text { Hydrous Fe(III) Oxide } \\
\text { Ferrihydrite }\end{array}$ & $\begin{array}{c}62 \pm 9 \\
40 \pm 10\end{array}$ & 0.027 \\
\hline
\end{tabular}


Table 3. Coordination numbers, interatomic distances, and Debye-Waller factors for As sorbed to iron minerals.

\begin{tabular}{|c|c|c|c|c|c|c|c|c|c|c|c|}
\hline & \multicolumn{4}{|c|}{ As-O } & \multicolumn{4}{|c|}{ As-Fe mononuclear } & \multicolumn{3}{|c|}{ As-Fe binuclear } \\
\hline & [As] $\left(\mathrm{mg} \mathrm{g}^{-1}\right)$ & $\mathrm{N}$ & $R(\AA)$ & $\sigma^{2}\left(\AA^{2}\right) \dagger$ & $\mathrm{N}^{\S}$ & $R(\AA)$ & $\sigma^{2}\left(\AA^{2}\right)^{\dagger}$ & $f$ & $\mathrm{~N}^{\S}$ & $R(\AA)$ & $\sigma^{2}\left(\AA^{2}\right)^{\dagger}$ \\
\hline As(III)-ferrihydrite & 24 & $2.8 \pm 0.4$ & $1.76 \pm 0.01$ & $0.003 \pm 0.002$ & 1 & $2.88 \pm 0.03$ & $0.003 \pm 0.002$ & $0.6 \pm 0.1$ & 2 & $3.39 \pm 0.03$ & $0.003 \pm 0.003$ \\
\hline Low As(III)_EnvFe(III) & 8 & $2.8 \pm 0.5$ & $1.76 \pm 0.01$ & $0.004 \pm 0.002$ & 1 & $2.90 \pm 0.05$ & $0.005 \pm 0.003$ & $0.4 \pm 0.2$ & 2 & $3.38 \pm 0.03$ & $0.005 \pm 0.003$ \\
\hline High As(III)_EnvFe(III) & 24 & $2.6 \pm 0.4$ & $1.77 \pm 0.01$ & $0.003 \pm 0.002$ & 1 & $2.88 \pm 0.03$ & $0.005 \pm 0.003$ & $0.5 \pm 0.2$ & 2 & $3.38 \pm 0.03$ & $0.005 \pm 0.003$ \\
\hline As(III)- ferrihydrite ${ }^{\ddagger}$ & 15 & 3.39 & 1.78 & 0.004 & 0.8 & 2.92 & 0.008 & N/A & 0.83 & 3.43 & 0.008 \\
\hline As(III)- ferrihydrite $h^{\text {II }}$ & 40 & 2.8 & 1.76 & 0.005 & 0.6 & 2.92 & 0.008 & N/A & 0.8 & 3.40 & 0.008 \\
\hline As(III)- ferrihydrite ${ }^{\S}$ & 27 & 3.07 & 1.79 & 0.0046 & N/A & N/A & N/A & N/A & 2 & 3.38 & 0.0100 \\
\hline
\end{tabular}

$\mathrm{S}_{0}{ }^{2}=0.8585$ (Foster et al., 1998; Paktunc et al., 2003); ${ }^{\S}$ fixed coordination numbers; ${ }^{\dagger}$ linked parameters; ${ }^{\dagger}$ Gao et al. (2013);

${ }^{\mathbb{I I}}$ Ona-Nguema et al. (2005); ${ }^{\S}$ Voegelin et al. (2007).

\begin{tabular}{|c|c|c|c|c|c|c|c|}
\hline & & \multicolumn{3}{|c|}{ As-O } & \multicolumn{3}{|c|}{ As-Fe binuclear } \\
\hline & {$[\mathrm{As}](\mathrm{mg} / \mathrm{g})$} & $\mathrm{N}$ & $R(\AA)$ & $\sigma^{2}\left(\AA^{2}\right) \dagger$ & $\mathrm{N}$ & $R(\AA)$ & $\sigma^{2}\left(\AA^{2}\right)^{\dagger}$ \\
\hline $\operatorname{As}(V)$-ferrihydrite & 24 & $3.2 \pm 0.6$ & $1.68 \pm 0.01$ & $0.001 \pm 0.002$ & $1 \pm 3$ & $3.31 \pm 0.05$ & $0.01 \pm 0.01$ \\
\hline Low As(V)_EnvFe(III) & 8 & $3.7 \pm 0.7$ & $1.68 \pm 0.01$ & $0.001 \pm 0.001$ & $1 \pm 3$ & $3.30 \pm 0.05$ & $0.01 \pm 0.01$ \\
\hline $\operatorname{High} \mathrm{As}(\mathrm{V}) \_\operatorname{EnvFe}(\mathrm{III})$ & 24 & $3.5 \pm 0.7$ & $1.67 \pm 0.01$ & $0.001 \pm 0.001$ & $2 \pm 3$ & $3.29 \pm 0.05$ & $0.01 \pm 0.01$ \\
\hline $\operatorname{As}(\mathrm{V})$-ferrihydrite ${ }^{¥}$ & 15 & 4 & 1.68 & 0.0029 & 1.3 & 3.27 & 0.0042 \\
\hline $\operatorname{As}(V)$-ferrihydrite ${ }^{t}$ & 24 & 4 & 1.67 & 0.002 & 1.8 & 3.3 & 0.01 \\
\hline As(V)-ferrihydrite ${ }^{\#}$ & 12.5 & 3.79 & 1.663 & 0.0035 & 2.57 & 3.26 & 0.011 \\
\hline As(V)-ferrihydrite ${ }^{+}$ & 24 & 4.0 & 1.69 & 0.0029 & 2.0 & 3.27 & 0.0061 \\
\hline As $(V)$-ferrihydrite ${ }^{\S}$ & 27 & 4.05 & 1.69 & 0.0026 & 2 & 3.31 & 0.0103 \\
\hline
\end{tabular}

$\mathrm{S}_{0}{ }^{2}=0.85$ (Foster et al., 1998; Paktunc et al., 2003); ${ }^{\dagger}$ linked parameters; ${ }^{\ddagger}$ Gao et al. (2013), $\mathrm{pH}=9$; ${ }^{\epsilon}$ Sherman and Randall (2003); ${ }^{*}$ Waychunas et al. (1993); ${ }^{+}$Das et al. (2014); ${ }^{\S}$ Voegelin et al. (2007). 
Table 4. Freundlich parameters used to model As(V) and As(III) sorption to synthetic 2-line ferrihydrite and environmental Fe(III) biomineral samples normalized to mass. $K_{f}=$ sorption constant; $\mathrm{n}=$ exponential constant; $\mathrm{E}=$ model efficiency.

\begin{tabular}{ccccc}
\hline & Data Set & $\boldsymbol{K}_{\boldsymbol{f}}\left(\boldsymbol{\mu} \mathbf{m o l} \mathbf{A s} \mathbf{g}^{-\mathbf{1}}\right)$ & $\boldsymbol{n}$ & $\mathbf{E}$ \\
\hline As(V) & Synthetic & $170 \pm 10$ & $0.17 \pm 0.03$ & 0.919 \\
& Env_6/19/15 & $250 \pm 10$ & $0.21 \pm 0.02$ & 0.984 \\
& Env_8/22/15 & $190 \pm 9$ & $0.17 \pm 0.01$ & 0.992 \\
As(III) & Env_1/8/16 & $320 \pm 10$ & $0.18 \pm 0.02$ & 0.974 \\
& Synthetic & $400 \pm 10$ & $0.33 \pm 0.02$ & 0.944 \\
& Env_9/11/15 & $190 \pm 10$ & $0.31 \pm 0.03$ & 0.933 \\
& Env_1/8/16 & $360 \pm 10$ & $0.36 \pm 0.02$ & 0.976 \\
& Env_2/1/16 & $370 \pm 10$ & $0.32 \pm 0.02$ & 0.962 \\
\hline
\end{tabular}


Table 5. Freundlich parameters used to model As(V) and As(III) sorption to synthetic 2-line ferrihydrite and environmental Fe(III) biomineral samples normalized to surface area. $K_{f}=$ sorption constant; $n=$ exponential constant; $\mathrm{E}=$ model efficiency.

\begin{tabular}{ccccc}
\hline & Data Set & $\boldsymbol{K}_{f}\left(\boldsymbol{\mu} \mathbf{m o l ~ A s ~ ~ ^ { - 2 }}\right)$ & $\boldsymbol{n}$ & $\mathbf{E}$ \\
\hline As(V) & Synthetic & $0.80 \pm 0.1$ & $0.18 \pm 0.02$ & 0.915 \\
& Env_6/19/15 & $2.0 \pm 0.3$ & $0.21 \pm 0.02$ & 0.984 \\
& Env_8/22/15 & $2.4 \pm 0.1$ & $0.16 \pm 0.01$ & 0.992 \\
& Env_1/8/16 & $2.4 \pm 0.3$ & $0.15 \pm 0.01$ & 0.983 \\
& Combined Env. & $2.0 \pm 0.3$ & $0.19 \pm 0.03$ & 0.979 \\
& Synthetic & $1.9 \pm 0.3$ & $0.33 \pm 0.04$ & 0.954 \\
& Env_9/11/15 & $2.4 \pm 0.3$ & $0.31 \pm 0.03$ & 0.933 \\
& Env_1/8/16 & $2.4 \pm 0.1$ & $0.36 \pm 0.03$ & 0.976 \\
& Env_2/1/16 & $1.9 \pm 0.4$ & $0.40 \pm 0.04$ & 0.976 \\
& All Combined & $2.3 \pm 0.3$ & $0.31 \pm 0.04$ & 0.972 \\
\hline
\end{tabular}




\section{Figures.}

Figure 1. TEM images of environmental Fe(III) mineral (A) and synthetic 2-line ferrihydrite (B) samples. The environmental Fe(III) mineral is morphologically consistent with those produced by iron-oxidizing bacteria.

Figure 2. Fe K-edge (A) XANES and (B) EXAFS spectra for Fe(III) mineral standards and samples. Linear combination fitting was performed for each sample of the three differing formation settings and is represented with an overlain dashed line, with fit parameters shown in Table 3.

Figure 3. Mass-normalized sorption of (A) As(V) and (B) As(III) sorption to environmental $\mathrm{Fe}(\mathrm{III})$ and synthetic 2-line ferrihydrite. All data was modeled using a Freundlich sorption isotherm model, with fit parameters shown in Table 4.

Figure 4. Surface area normalized sorption of (A) As(V) and (B) As(III) to environmental $\mathrm{Fe}(\mathrm{III})$ biominerals and synthetic 2-line ferrihydrite. All data was modeled using a Freundlich sorption isotherm model, with fit parameters shown in Table 5.

Figure 5. As K-edge (A) XANES, (B) EXAFS spectra, and (C) FT magnitude plots Fe(III) standards and minerals used in sorption isotherm experiments. Fits to the data based on structural models are represented with an overlain dashed line with fit parameters shown in Table 3. 

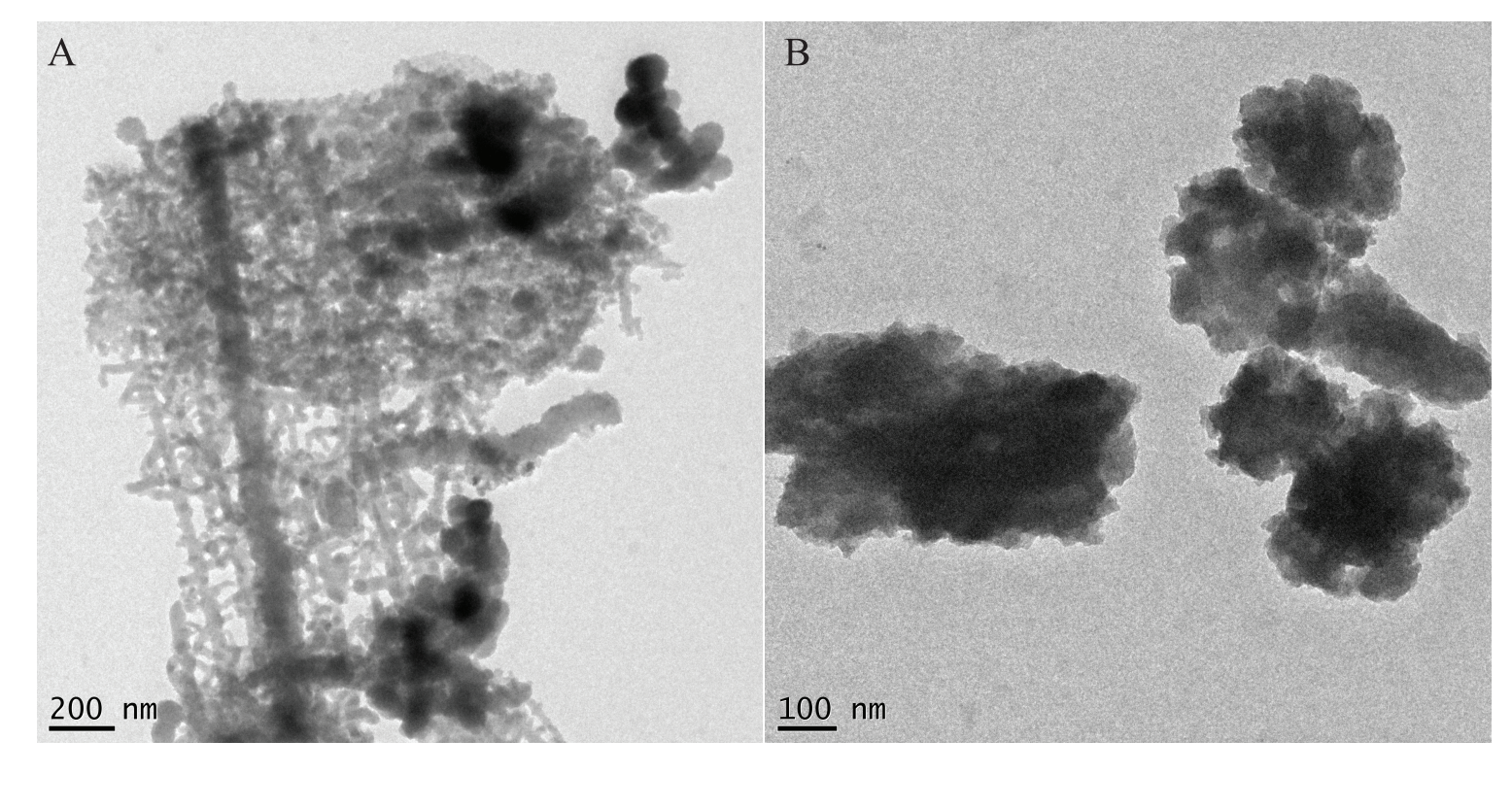

Figure 1

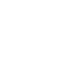
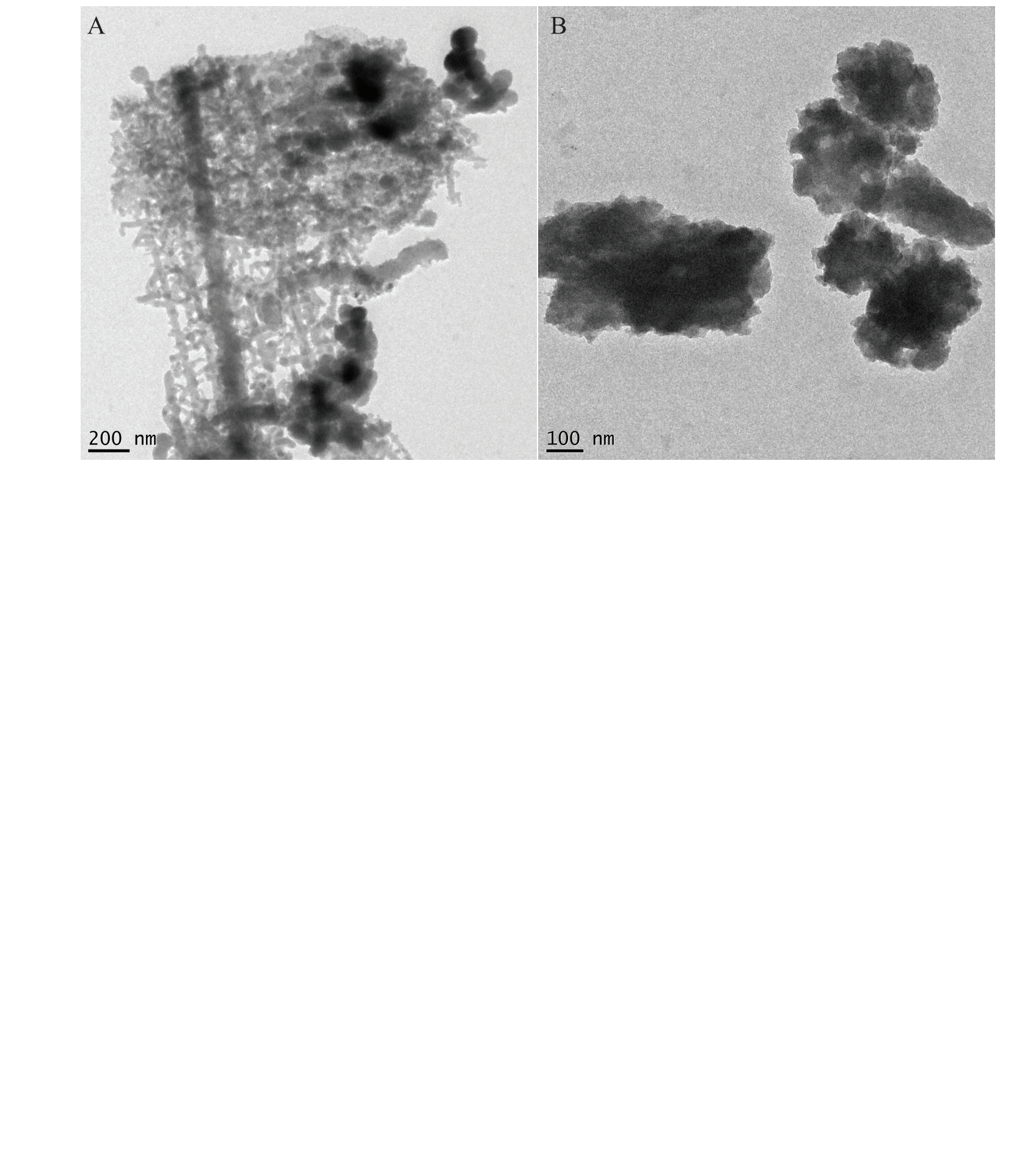

\section{Fig 1. \\ Fig 1.}




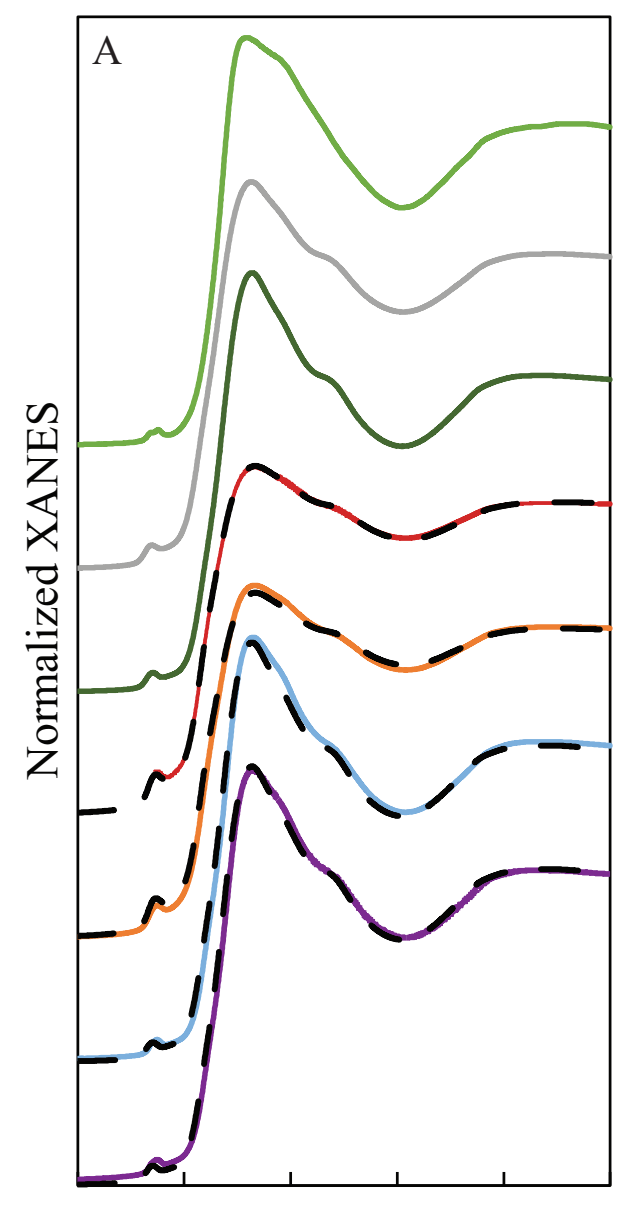

710071207140716071807200 Energy (eV)

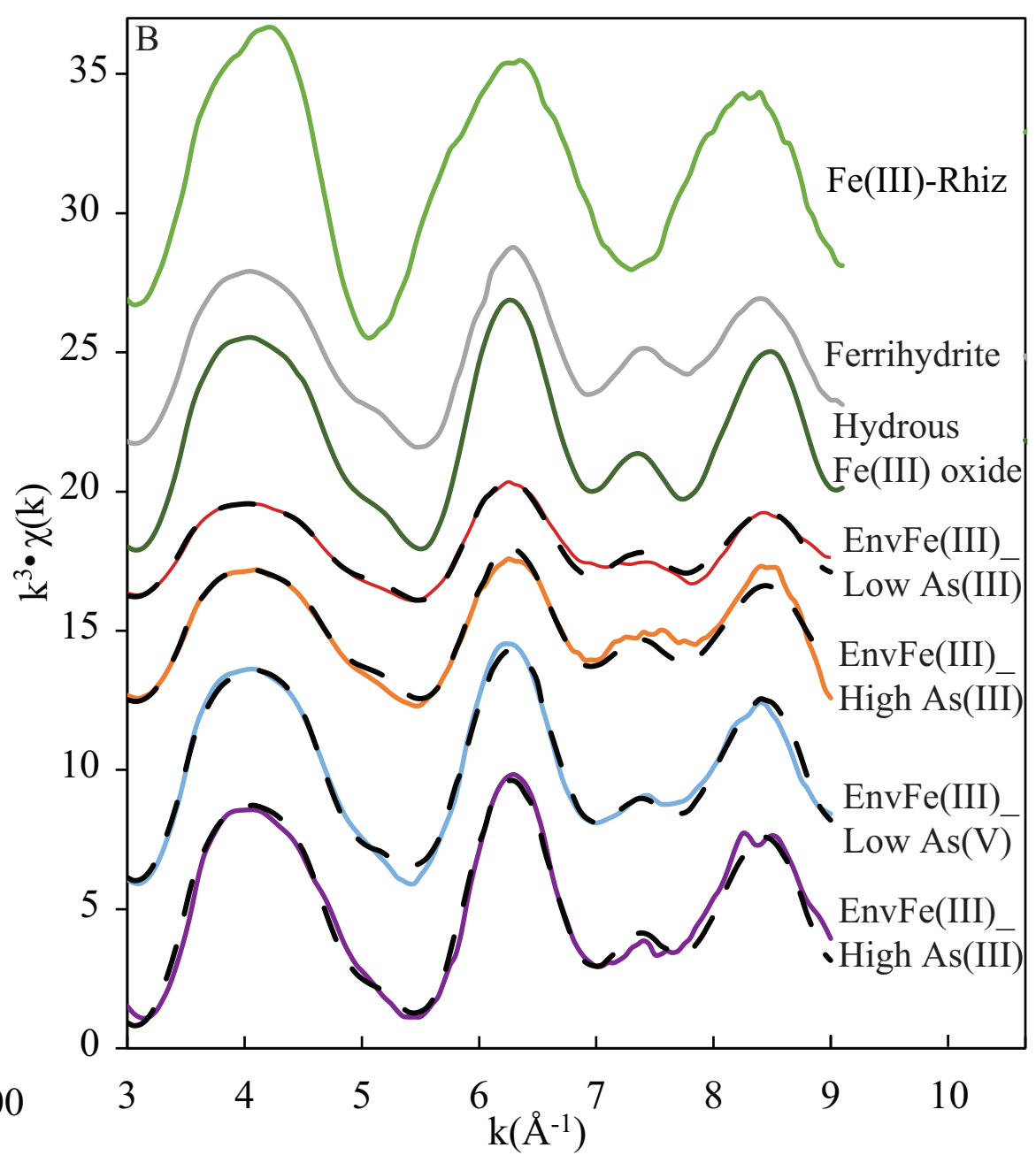

Fig. 2. 
Figure 3

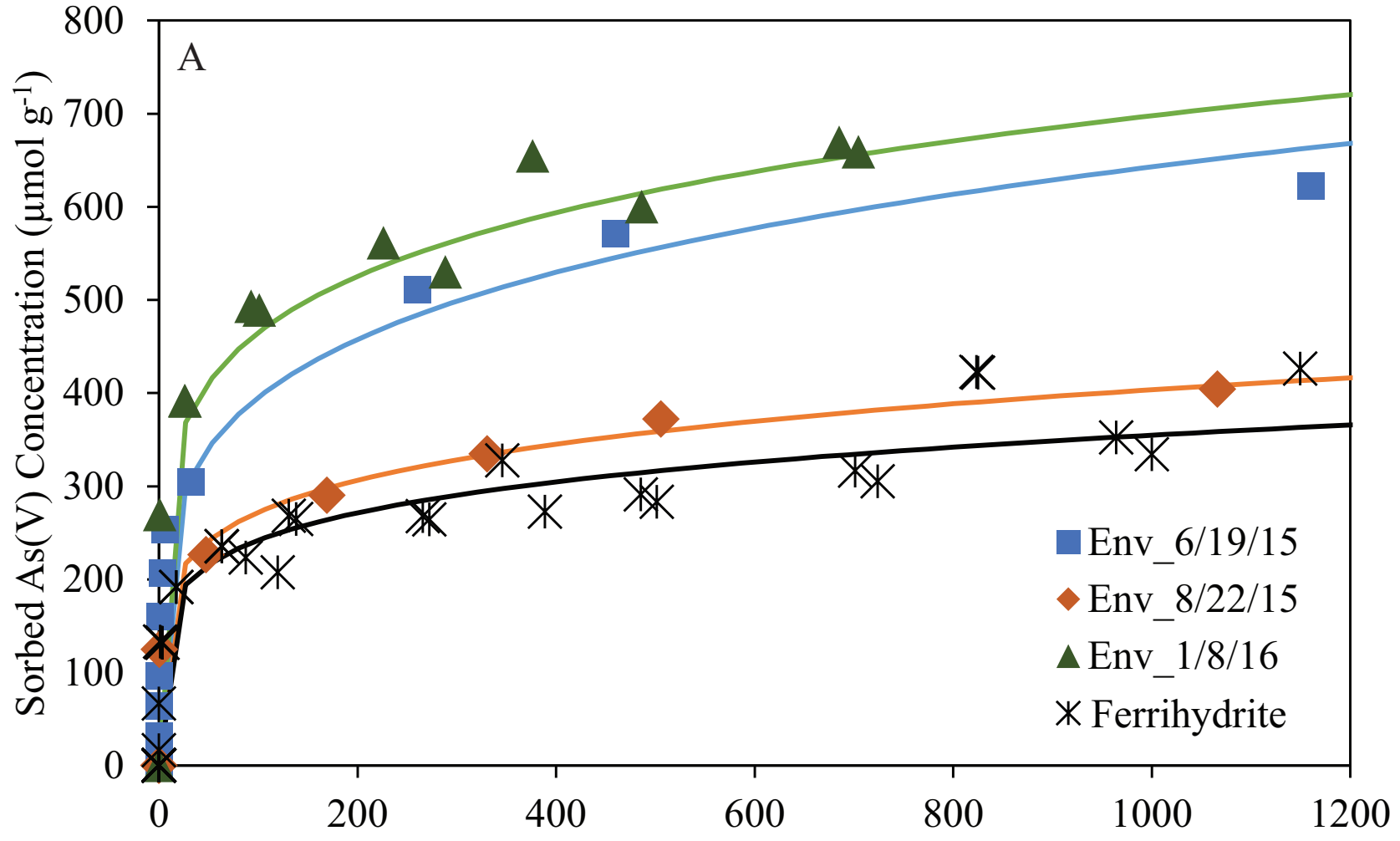

Dissolved As Concentration $(\mu \mathrm{M})$

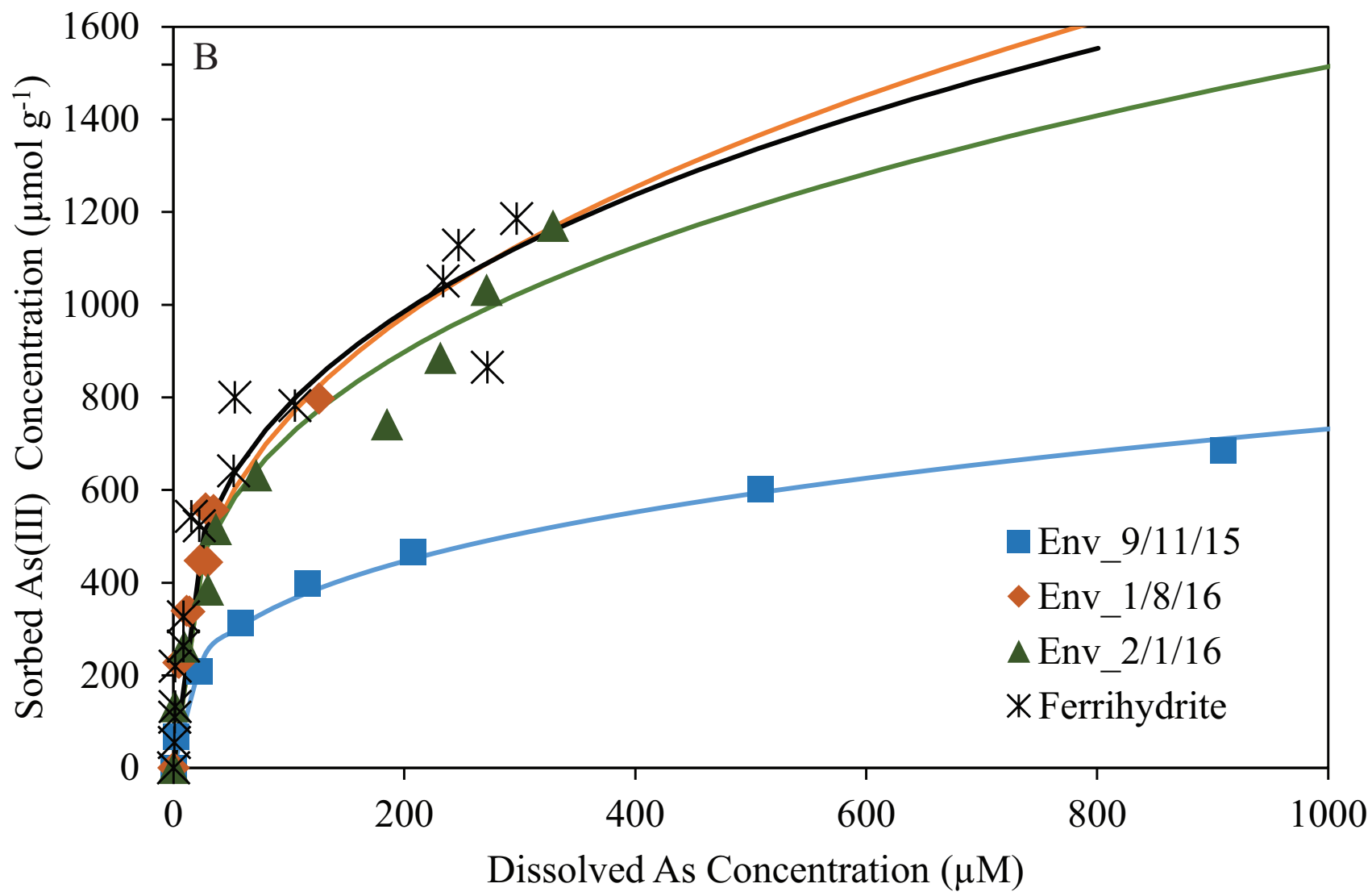

Fig 3. 

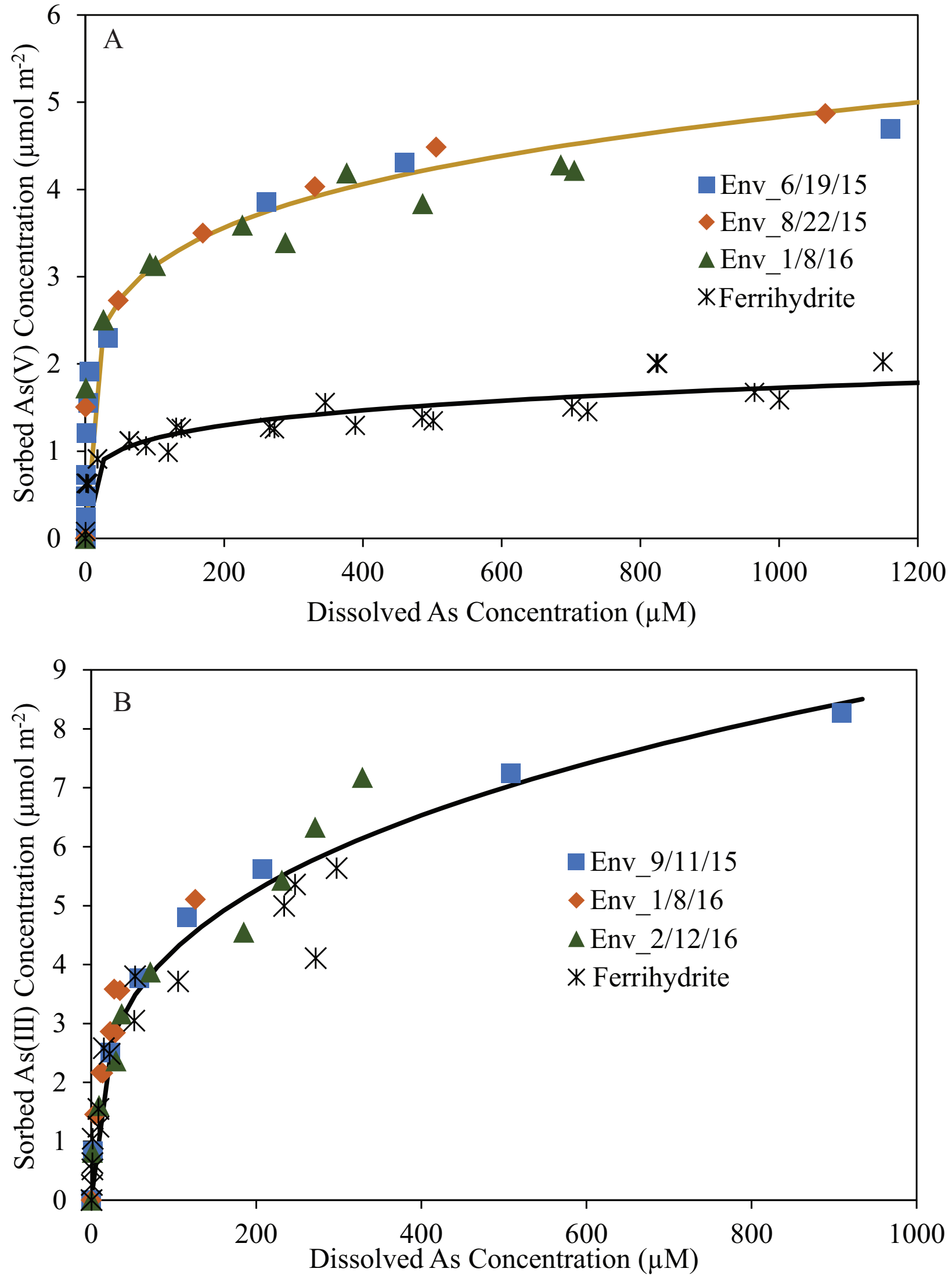

Fig 4. 

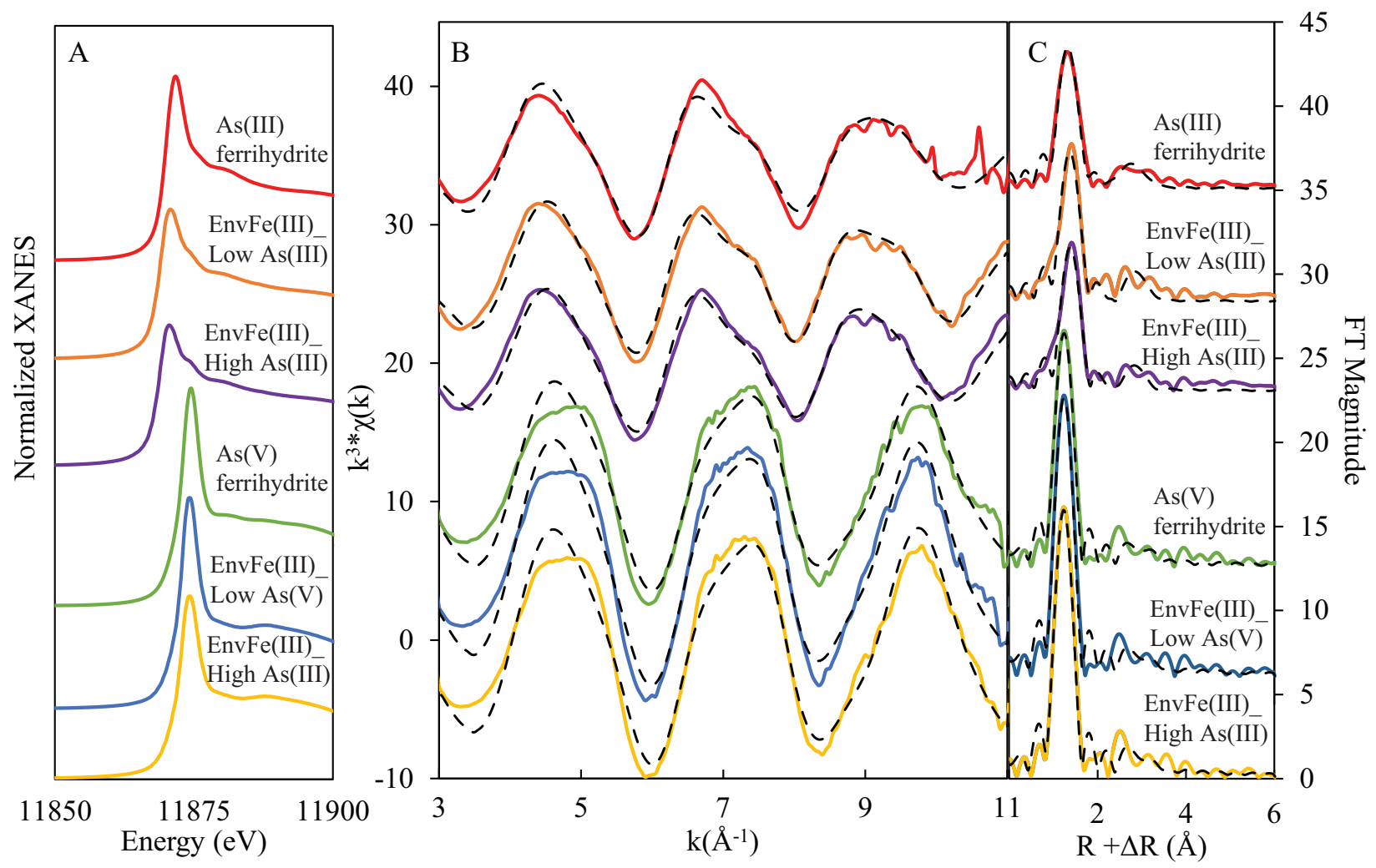

Fig. 5. 